

\section{INTERNAUKA \\ in ternauka .org}

\section{INNOVATIONS AND TENDENCIES OF STATE-OF-ART SCIENCE}

Proceedings of V-VI International Multidisciplinary Conference

April, 2021

Rotterdam, Nederland

2021 
V-VI International Multidisciplinary Conference "Innovations and Tendencies of State-of-Art Science". Proceedings of the Conference (April, 2021). Mijnbestseller Nederland, Rotterdam, Nederland. 2021. 92 p

Editor-in-Chief:

Anatoly A. Enikeev - Candidate of Philosophical Sciences, Associate Professor, Department of Philosophy, Kuban State Agrarian University, Krasnodar

Editorial Board:

Urfan Tagiev - Candidate of Technical Sciences

Oleg Kharchuk - Candidate of Biological Sciences

Alla Zlivko - Candidate of Juridical Sciences

Khotamjon Kobulov - Candidate of Economic Sciences

Nurgul Smagulova - Candidate of Philological Sciences

Shamil Azizov - Candidate of Geographical Sciences

Lamjav Olzvoibaatar - Doctor of Technical Sciences

Included to the open access repositories:

\section{CLIBRARY.RU}

ISBN 978-94-036-1025-2

(C) Mijnbestseller Nederland, 2021

(C) Internauka, LLC, 2021 


\section{Table of Content}

Section 1. Biological sciences $\quad 6$

PROMISING TYPES OF POLYSACCHARIDE RAW 6

MATERIALS FOR BIOTECHNOLOGICAL PROCESSING

Bahytzhan Kedel'baev

Gul'den Nysanbaeva

Dariha Kudasova

Section 2. Education and pedagogy 11

EFFECTIVE WAYS TO INTEGRALLY ASSESS WRITING

AND READING SKILLS IN THE KAZAKH LANGUAGE

Zhaina Rustemova

Karlygash Kuneva

FORMATION OF INTEREST IN THE CREATIVE

PROCESS OF EDUCATIONAL AND COGNITIVE

16

ACTIVITY THROUGH EXTRACURRICULAR ACTIVITIES

Ayshe Tashbaeva

\section{Section 3. Engineering}

DESIGN ENCODER FOR 14 NM PROCESS AND STUDY

OF CHANGES IN PROPERTIES AS A CHANGE OF

TEMPERATURE

Armen Babayan

VARIATIONS OF OPERATIONAL AMPLIFIER

FREQUENCY PARAMETERS DEPENDING ON RANDOM

DEVIATIONS OF THE 16NM TECHNOLOGICAL

PROCESS TRANSISTORS

Vazgen Gevorgyan

USE OF LOCAL NETWORK PREVENTION METHODS

OF ENTERPRISES AND ORGANIZATIONS BASED ON

DLP TECHNOLOGY (DATA LEAK PREVENTION)

Aisultan Kharakozha

V.A. Kobzarev

DEPENDENCY MANAGEMENT AND BUILD TOOLS

IN JAVA

Narek Naltakyan

DESIGN PATTERNS IN PROGRAMMING

Aghasi Seyranyan 
THE ESSENCE AND RELEVANCE OF THE USE

OF CLOUD ERP SYSTEMS

Aigerim Zhumanova

Vasily Serbin

RESEARCH OF BIO-PACKAGES AND CHARACTERISTICS

OF PACKAGING MATERIALS

Kuanyshbekov Nurzhan

Askarbekov Erik Birlikovish

\section{Section 4. Pharmaceutical sciences}

USING THE EDUCATIONAL INSTITUTION SITE FOR

MIXED EDUCATION IN HIGHER PHARMACEUTICAL

EDUCATION

Tatiana Litvinova

Evgeniia Budenkova

Liudmila Babaskina

Dmitrii Babaskin

Irina Galuzina

\section{Section 5. Philology}

SYNTACTICAL STYLISTIC WAYS OF CREATING IRONY IN ENGLISH LANGUAGE

Angelina Bakhanovich

IDENTIFICATION OF THE ELDER AGE IN RUSSIAN

AND CHINESE LANGUAGES

Yan Zhuo

\section{Section 6. Economics}

METHODS OF STATE REGULATION OF THE ECONOMY: $\quad 73$ THE ROLE OF MONETARY RELATIONS

Ruslan Laliev

SOME ASPECTS OF THE FORMATION OF THE

COMPETITIVENESS OF PRIVATE DENTAL

ORGANIZATION LLC "KOMODSKIY VARAN"

Darya Naiden

Olga Balabanovich 
NOWADAYS GAMBLING INDUSTRY REGULATION IN

RUSSIA AND EX-USSR

Helga Ozolina

ON THE NEED TO STRENGTHEN THE PROTECTION OF

88

VIRTUAL SPACE IN THE CONTEXT OF A PANDEMIC

Olga Korotkova 


\section{SECTION 1.}

\section{BIOLOGICAL SCIENCES}

\section{PROMISING TYPES OF POLYSACCHARIDE RAW MATERIALS FOR BIOTECHNOLOGICAL PROCESSING}

Bahytzhan Kedel'baev

Doctor of Technical Sciences, professor, M. Auezov South Kazakhstan State University, Kazakhstan, Shymkent

Gul'den Nysanbaeva

Master's degree student, M. Auezov South Kazakhstan State University, Kazakhstan, Shymkent

Dariha Kudasova

Master, lecturer, M. Auezov South Kazakhstan State University, Kazakhstan, Shymkent

\section{БИОТЕХНОЛОГИЯЛЫК ӨНДЕУГЕ АРНАЛҒАН ПОЛИСАХАРИДТІ ШИКІЗАТТЫН ПЕРСПЕКТИВТІ ТУРЛЕРІ}

Кедельбаев Бахытжан техника вылымдарының докторы, профессор, М.Әуезов атындагы Оңтүстік Қазақ̧стан мемлекеттік университеті, Қазақ̧стан, Шымкент к̧.

Нысанбаева Гульден магистрант, М.Әуезов атындавы Оңтүстік Қазақстан мемлекеттік университеті, Қазақсстан, Шымкент къ. 


\section{Кұдасова Дариха}

магистр, оқыьтушы,

М.Әуезов атындавы Оңтүстік

Қазақ̆стан мемлекеттік университеті, Қазақстан, Шымкент к̧.

Соңғы жылдары Қазақстан Республикасында биотехнология үшін шикізат көздерін қайта жаңартылмайтын көздерден (парафин, мұнай, газ, синтетикалық спирттер және органикалық қышқылдар) қайта жаңартылатын көздерге қайта бағдарлау жүргізілді. Отандық өнеркәсіптік биотехнологияның құлдырауының себептерінің бірі арзан көмірсутекті шикізатқа және оның химиялық түрлену өнімдеріне бағдарлануы болуы мүмкін [1]. Сонымен қатар, шикізаттың бұл түрінде биологиялық қауіпті қоспалар болды, оларды жою өндірісті қымбаттатты. Өткен жылдары көмірсулар шикізатының жеткілікті мөлшерде болмауы құрылған технологиялардың бәсекеге қабілетсіздігінің және ферменттер, амин қышқылдары, антибиотиктер және ірі тонналы биотехнологияның басқа да өнімдерін өндіруді тоқтатудың екінші себебі болды. Посткеңестік кезеңде тамақ биотехнологиясының белгілі бір табыстарымен қатар (сыра, ашыған сүт өнімдері мен ірімшік, тағамдық спирт өндірісі) Қазақстан Республикасының ірі тонналық биотехнология өнімдеріне, оның ішінде дәрілік препараттарға жаппай тәуелділік жағдайы қалыптасты.

Алайда биотехнологиялық өнеркәсіптің жаңа өрлеуі үшін ресурстар бар. Құрамында қант бар шикізат ретінде қант қызылшасы және қант өндірісінің өнімдері (қалдықтары): меласса, қызылша шырыны, сірне және т. б. сияқты ауылшаруашылық өнімдерін пайдалануға болады.

Құрамында қант бар шикізат-биоэтанолға технологиялық өңдеу үшін шикізаттың ең қарапайым және ыңғайлы түрі [2]. Бірақ, Қазақстан Республикасының, бүкіл әлем сияқты, жаһандық дағдарысқа енуіне байланысты елеулі теріс үрдістерді атап өтпеуге болмайды. Оның ең бастысы-ірі тоннажды биотехнологиялық өндірістерді дамыту үшін азық-түлік емес шикізаттың жеткілікті көмірсутекті шикізат базасының болмауы. Бұл даму дәнді және басқа да целлюлоза, қант және крахмал бар ауылшаруашылық өнімдері мен қалдықтарын кешенді терең өңдеу жағдайында ғана мүмкін болады [1].

Шикізатты барынша толық кешенді пайдалану, пайда болатын қайталама ресурстарды қауіпсіз және экономикалық тұрғыдан тиімді қайта өңдеу агропромы мол кешеннің өзекті мәселесі болып табылады [3].

Биоэтанолды өндіруге арналған құрамында крахмал бар негізгі шикізат ретінде дәнді дақылдардың сипаттамасы 1-кестеде келтірілген. 
Kecme 1.

Биоэтанол өндіруге арналған шикізат ретінде дәнді дақылдардың сипаттамасы [2]

\begin{tabular}{|l|c|c|c|c|}
\hline \multicolumn{1}{|c|}{ Көрсеткіші } & \multicolumn{4}{|c|}{ Шикізат } \\
\hline $\begin{array}{l}\text { Орташа өнімділік, } \\
\text { ц/га }\end{array}$ & Бидай & Қара бидай & Арпа & Жүгері \\
\hline $\begin{array}{l}\text { Крахмалдың орташа } \\
\text { мөлшері, \% }\end{array}$ & 53,91 & 18,7 & 24,4 & 32,5 \\
\hline $\begin{array}{l}\text { өндірісі: } \\
\text { - крахмалдың, ц/га } \\
- \text { биоэтанолдың, } \\
\text { дал/га }\end{array}$ & 14,28 & 9,98 & 51,3 & 58,1 \\
\hline $\begin{array}{l}\text { Этанолдың, л 1 } \\
\text { тоннадан }\end{array}$ & 375 & 35,69 & 12,52 & 18,88 \\
\hline $\begin{array}{l}\text { Кұрғақ барда, кг 1 } \\
\text { тоннадан }\end{array}$ & 330 & 390 & 430,19 & 125,1 \\
\hline С2 кг 1 тоннадан & 370 & 350 & 320 & 410 \\
\hline
\end{tabular}

Құрамында крахмал бар шикізат ретінде дәнді дақылдардың әртүрлі түрлерінен басқа (қара бидай, арпа, жүгері, бидай және т.б., [2]) картоп, топинамбур, цикорий сияқты ауылшаруашылық өнімдерін пайдалануға болады.

Биоэтанол өндіру үшін өсімдік шикізатын таңдау критерийлері: төмен құны; жоғары шығымдылығы және крахмал (қант) құрамы; зиянкестер мен вирустарға төзімділігі; жыл бойы қол жетімділігі және болуы; топырақ пен ауа-райы жағдайларына төмен талап етілуі; жинау, тасымалдау және жеткілікті сақтаудың аз еңбек сыйымдылығы; қалдықтарды қайта өңдеу мүмкіндігі (қосымша пайда алу); қайта өндеу кезінде қосымша препараттарды (ферменттер, көбіктендіргіштер) пайдалануға болмашы қажеттілік [2].

Отын этанолын өндіруге арналған шикізат (ірі тонналық биотехнология өнімі ретінде) шаруашылықты энергетикалық қайта бейіндеудің бастапқы кезеңінде мынадай бірқатар талаптарға сәйкес келуі тиіс: дереу пайдалану мүмкіндігі; шикізатты фракциялау және (немесе) қалдықтарды қайта өңдеу есебінен қосымша өнім өндіру мүмкіндігі; негізгі және жанама өнімнің жоғары сапасын қамтамасыз ету; өндірістің жоғары экономикалық тиімділігіне кепілдік беретін дайын технологиялар мен ғылыми әзірлемелердің болуы [4-6].

Қазақстан Республикасында бар ресурстардың осы талаптарына қызылша сығындысы, қант қызылшасы, кондицияланбаған астық, күнжара 
жауап береді.

Қазақстан Республикасында ауыл шаруашылығының қалдықтары бүгінде сұранысқа ие емес ресурс болып табылады, сабанның барлық көлемінің тек $10 \%$ - ы ғана пайдаланылады, негізінен мал шаруашылығында. Сонымен қатар, топырақтың құрылымын жақсарту үшін сабан көбінесе жерге жағылады немесе иістенеді. Бірақ бұл гидролизден және биотехнологиялық өңдеуден кейін құрамында қант бар жем, ақуыз және биоэтанолдың қосымша көзі бола алатын құнды шикізат [1]. Сабан отын спиртін өндіруге арналған ең арзан және қолда бар шикізат болып табылады.

Өсімдік шикізатында аз мөлшерде майлар мен ақуыздар, гемицеллюлозалардың көп мөлшері және полисахаридтері бар, олар негізінен көмірсулармен қоректенуді алмастыра алады, алайда бұл өсімдік материалдарын лигно-көмірлі байланыстардың болуына байланысты табиғи түрде тамақтандыру кезінде жануарлар оларды нашар сіңіреді. Әр түрлі дақылдардың сабанының құрамы 2 [7] кестеде келтірілген.

Kecme 2.

Табиғи ылғалдылықтағы сабанның құрамы, массалық үлесі

\begin{tabular}{|l|c|c|c|c|c|}
\hline $\begin{array}{c}\text { Сабанның } \\
\text { түрі }\end{array}$ & Протеин & Май & Талшық & $\begin{array}{c}\text { Азотсыз } \\
\text { эксрактивті } \\
\text { заттар }\end{array}$ & Күл \\
\hline Сұлы & 5,12 & 1,69 & 37,60 & 35,90 & 4,79 \\
\hline $\begin{array}{l}\text { Қара бидай } \\
\text { ұны }\end{array}$ & 3,65 & 1,48 & 40,37 & 36,18 & 3,40 \\
\hline Бидай жаздық & 4,26 & 1,47 & 37,90 & 36,60 & 3,78 \\
\hline Бидай күздік & 3,86 & 1,38 & 34,10 & 33,60 & 3,54 \\
\hline
\end{tabular}

Тағамдық емес шикізатты, оның ішінде ауылшаруашылық қалдықтарын биоөнімдерге айналдыру процесінің анықтайтын технологиялық кезеңі-сахарификация кезеңі. Оны қышқылдар, сілтілер немесе ферменттер көмегімен жасауға болады.

Ферменттік препараттар саласындағы қарқынды дамуларға қарамастан, целлюлазалардың жеткілікті бәсекеге қабілетті түрлері әлі де жасалмаған. Сондықтан целлюлоза бар шикізатты ашытудың күрделілігі оны кеңінен қолдануға негізгі кедергі болып табылады [2]. Ал нарыққа түсетін тауарлық ферменттерді, сондай-ақ ферменттік препараттардың тәжірибелік партияларын мониторингтеу міндеті бұрынғыдан да өзекті болып табылады. 


\section{Пайдаланған әдебиеттер тізімі:}

1. Нуртдинов Р.М. Разработка биотехнологического комплекса переработки растительного сырья и отходов сельскохозяйственного производства / Р.М. Нуртдинов, С.Г. Мухачев, Р.Т. Валеева, В.М. Емельянов, М.Ф. Шавалиев, И.В. Шагивалеев, И.А. Якушев // Вестник Каз. технол. ун-та.-2011. №2.- С. 143- 147.

2. Щуцкий И.В. Этанол - новое направление компании. Свежий взгляд на старые проблемы / И.В. Щуцкий, О.Г. Галузинский // Сахар. - 2008. №5. С. 81-90.

3. Быков В.А. Перспективы производства растительно - углеводного корма на основе гидролиза древесины и других растительных материалов / В.А. Быков, В.В. Головин, И.И. Корольков // Гидролизная и лесохимическая промышленность. - 1982.- № 5.- С. 4-6

4. Осипова В.Н. Особенности гидролиза природных полисахаридов сернистой кислотой / В.Н.Осипова, Р.Т. Валеева, С.Г. Мухачев, Р.М. Нуртдинов, Р.Р. Гараева // Синтез, исследование свойств, модификация и переработка высокомолекулярных соединений - V Кирпичниковские чтения. Тезисы докладов. ХІІІ Международная конференция молодых ученых, студентов и аспирантов. - Казань. - 2009. - С. 348.

5. Осипова В.Н. Гидролиз природных полисахаридов кислотами / В.Н. Осипова, Р.М. Нуртдинов, Р.Т. Валеева, С.Г. Мухачев // Сб.: IX Республиканская школа студентов и аспирантов «Жить в XXI веке».Казань.- Из-во Казан, гос. технол. ун-та. 2010. - т.1.- С. 221- 222.

6. Стенькина А.И. Возможности использования гидролизата свекловичного жома в производстве топливного этанола /А.И. Стенькина, М.Ф. Шавалиев, С.Г. Мухачев, Р.Т. Валеева // VIII Всероссийская конференция молодых ученых с международным участием «Пищевые технологии» (г. Казань, 9-10 апреля 2007 г.). Сб. тезисов докл.- Казань: Изд-во «Отечество». -2007.C. 232.

7. Тарабанько В.Е. Исследование процесса переработки пшеничной соломы в ароматические альдегиды и левулиновую кислоту /В.Е. Тарабанько [и др.]. // Химия растительного сырья. -1998.- №3.- С. 59-64. 


\title{
SECTION 2.
}

\section{EDUCATION AND PEDAGOGY}

DOI: 10.32743/NetherlandsConf.2021.3.5.255204

\section{EFFECTIVE WAYS TO INTEGRALLY ASSESS WRITING AND READING SKILLS IN THE KAZAKH LANGUAGE}

\author{
Zhaina Rustemova \\ Master of pedagogical and psychological sciences, \\ Center for Pedagogical Measurements AEO \\ «Nazarbayev Intellectual Schools», \\ Kazakhstan, Nur-Sultan \\ Karlygash Kuneva \\ Center for Pedagogical Measurements AEO \\ "Nazarbayev Intellectual Schools», \\ Kazakhstan, Nur-Sultan
}

\section{КАЗАҚ ТІЛІ ПӘНІНДЕГІ ЖАЗЫЛЫМ ЖӘНЕ ОҚЫЛЫМ ДАҒДЫЛАРЫН БІРІКТІРЕ БАҒАЛАУДЫН ТИІМДІ ЖОЛДАРЫ}

\author{
Рустемова Жайна Жарасовна \\ педагогика және психология выльимдарының магистрі, \\ «Назарбаев Зияткерлік мектептері» ДББҰ \\ «Педагогикалық өлшеулер орталыгы», \\ Қазақсстан, Нұр-Сұлтан қ. \\ Кунева Карлыгаш Елеусизовна \\ «Назарбаев Зияткерлік мектептері» \\ ДББҰ «Педагогикальқ өлшеулер орталывы»», \\ Қазақсстан, Нұр-Сұлтан қ.
}




\begin{abstract}
The article describes the features of assessing the reading skills of the Kazakh language in Nazarbayev Intellectual Schools. Reading skills are one of the key factors in improving students' functional literacy. The author believes that one of the most effective ways of assessing reading skills in exams is the teacher's feedback on the student's work. He gives examples to prove his point.

\section{АННОТАЦИЯ}

В статье описаны особенности оценки навыков чтения казахского языка в Назарбаев Интеллектуальных школах. Навыки чтения являются одним из ключевых факторов повышения функциональной грамотности учащихся. Автор считает, что одним из наиболее эффективных способов оценки навыков чтения на экзаменах является обратная связь учителя работе учащегося. Он приводит примеры, чтобы доказать свою точку зрения.
\end{abstract}

Keywords: Kazakh language, reading skills, assessment of reading skills, students' functional liteacy, teacher's feedback.

Ключевые слова: казахский язык, навык чтения, функциональная грамотность, оценивания, обратная связь.

Білім беру мазмұны жаңартылып жатқан кезеңде заман талабына сай бәсекеге қабілетті тұлғаны дайындау, өмірге бейімдеу, функционалды сауаттылығын арттыру басты міндетіміз. Мектеп оқушыларға тек білім беріп қана қоймай, сонымен бірге оқушылардың білімін бағалау, оқушыларды алға ұмтылуға ынталандыру орталығы болып есептеледі. Ал оқушының дұрыс қалыптасуындағы шешуші рөлді бағалау атқаратыны сөзсіз. Яғни білім сапасын көтерудің бір үлкен көрсеткіші - бағалау. Бағалау оқытудың ажырамас бір бөлігі болып табылады, ол оқу бағдарламасындағы мақсаттармен, күтілетін нәтижелермен тікелей байланысты.

Назарбаев Зияткерлік мектептерінде қалыптастырушы бағалау, ішкі жиынтық бағалау, сыртқы жиынтық бағалау түрлерін қамтитын критериалды бағалау жүйесі қолданылып, оқытудың сапасын жақсартудың бірден-бір жолы екенін дәлелдеуде. Оқушылар мұнда нәтижені талдау үшін бағалау критерийлерін білуге, түсінуге, рефлексияға қатысуға, яғни өзін және өз достарын бағалауға, нақты тапсырмаларды орындауда өз білімдерін қолдануға, ойларын еркін жеткізе білуге, сын тұрғысынан ойлай білуге дағдыланады. Қалай оқу керектігін пайымдайды. Осы мақалада Зияткерлік мектептердегі қазақ тілі пәнінен өтетін сыртқы жиынтық бағалаудың ерекшеліктеріне, оның ішінде оқылым дағдысының 
бағалау кезінде мұғалім пікірінің (жазбаша кері байланысының) маңыздылығына тоқталып, бірнеше үлгілерін көрсетпекпіз. Назарбаев Зияткерлік мектептерінде оқушылар білімінің сыртқы жиынтық бағалауы халықаралық A-level, AS-level және IGCSE нормалары мен талаптарына сай өткізіледі. 10-сыныптың «Қазақ тілі (бірінші тіл)» пәнін бағалау халықаралық IGCSE деңгейіне сәйкес келеді. Емтихан 2 жұмыстан тұрады. 1-емтихан жұмысы оқылым және мәтінді талдауға арналған. Бұл тапсырмада мәтіндердің айырмашылық ерекшеліктерін анықтап түсіндіру қабілеттері бағаланады. 2-емтихан жұмысы жазылымға арналған. Жазылымда оқушылардың шығарма жазу қабілеттері және тілдің көмегімен мұқият жоспарланған әрекетті құра алуы, сонымен бірге аргументтер келтіре отырып, жүйелі және сенімді жаза алу қабілеттері бағаланады.

Өз зерттеулерінде Ф.Оразбаева «Оқылымның берілген материалды түсініп, ұғу ғана емес, ондағы әрбір тілдік-қатысымдық тұлғалардың мағынасын білу, қалпын тану және оны тілдік қарым-қатынаста кеңінен пайдалану керектігінің» [1] маңызды екендігіне баса назар аударады. Мәтіндерге салыстырмалы анализ жасау мақсаты арқылы оқушы тек мәтін мазмұнын меңгеріп қана қоймай, сол мәтінді жазу арқылы автордың нені көздегенін, кімдерге арнағанын, автордың сол мәселеге байланысты қандай көзқараста екенін, оқырманға жеткізу үшін қолданған тілдік бірліктерін саралап, сараптама жасау дағдысын қалыптастырады.

Оқылым және мәтінді талдауға арналған тапсырмаларда оқушылардың мәтіндердің ерекше айырмашылықтарын анықтау қабілеттерін, өз жауаптарында ақпараттарды дұрыс ұйымдастыру мен жазылымның қызметін байланыстыра алуын, сөздік қоры секілді аспектілерге түсінік беруін, нақышты сөздерді қолдануын (мысалы, метафора мен теңеуді қолдану), сөздердің реті мен сөйлем құрылымын, коммуникациялық қарым-қатынасын, тысқары пікір мен алдын ала болжай алуын бағалайды. Оқушылардың емтихан жұмыстары нәтижелерін жақсарту мақсатында, олардың жазған жауаптарына тексеруші мұғалімдер тарапынан қойылған балға, бағаға сәйкес пікір (жазбаша кері байланыс) жазылады. "Балаға өз бетімен зерттеуге мүмкіндік туғызған сайын одан әрі жақсы оқи түседі”- деген Питер Клайнның сөзін [2] ескерсек, бағалаушы мұғалімнің оқушы жұмысына жазған пікірі оқушы тарапынан өзінің жетістігі мен кемшілігін түсінуге және өзін-өзі жетілдіруге деген қызығушылығын тудырып, өз бетінше ұмтылысын арттырады.

Оқылым және мәтінді талдау компонентіндегі тапсырмалар оқылым дағдысы бойынша оқушының жыл бойы алған білімі мен түсінігін, дағдысын қолдана алуына негізделген. Оқылымның 1(a) тапсырмасы бойынша өзара байланысы бар тақырыпқа қатысты мәтінге 
оқушы тілі мен стилі, формасы, ұқсастығы мен айырмашылығы, мақсаты мен мазмұнына, көзделген аудиториясы мен тіліне салыстырмалы талдау талап етіледі.

1 (а) тапсырмасы: екі мәтінді салыстырып, олардың тілі мен стилін, формасын, ұқсастығын және айырмашылығын сараптаңыз.

Төменде түрлі деңгейдегі оқушы жауаптарына берілген кері байланыс үлгісі берілген:

\section{А деңгейіндегі окушы жұмысына берілген кері байланыс}

Оқушы тапсырманы толық әрі нақты түсінгенін, теориялық білімін практикамен ұштастыра білгенін мәтін бойынша сараптаған жұмыстарынан көруге болады. Ғылыми сипаттағы А мәтінінің ғылыми аспектісі мен Ә мәтінінің ауызекі стиліндегі ерекшеліктерін құр баяндап немесе атап қана кетпей, мәтіндердің стильдік аспектілеріне негізделген белгілеріне орай оны жан-жақты сараптай алған. Мысалы, А мәтіні бойынша ғылыми журналдан алынған мақала екендігін мәтіндегі терминдер мен кәсіби сөздердің, белгілі фактілер мен деректердің мәтін мазмұнын ашудағы мақсаты мен мазмұнын сабақтастыра отырып талдаған. Ал, Ә мәтінін ауызекі сөйлеу стиліндегі блог жазбасы екендігін автордың сезімдерімен, эмоциялық реңкі басым болуымен байланыстыра сараптаған. Мәтіннің тілдік тұрғыдағы көріністерін шақ тұлғасында, сөйлем құрылымы бойынша, ал мәтіннің лексикасын (тура және ауыспалы мағынадағы сөздердің, термин сөздердің қолданысының дәлелдемелерге негізделгенін) тақырыпты ашу үшін орынды қолданған. Ә мәтініндегі ауыспалы мағынадағы сөздердің «адам аяzы баспаван табиват», «жарқыраван мұнара», «альіп мұздар» секілді эпиттерді мәтінге көркемдегіш ренк беріп, оқырманга ерекше әсер беру және өз сезімін жеткізу үшін қолданаван» деп дәлел келтіріп, мәтінмен сабақтастыра отырып талдаған. Сондай-ақ оқушы А және Ә мәтінінің морфологиялық және синтаксистік ерекшеліктеріне де аса мән берген. А мәтінінде көбіне етістіктің осы шақтағы тұлғасының қолданыста болғандығын, ғылыми стильде сөйлем түрлерінің барлығы еркін қолданыста болатындығын, құрмалас және жай сөйлем түрлерінің аралас жүруі ойдың айқын әрі бай екендігін көрсететіндігіне де талдау бере алған. Оқушының мәтінге салыстырмалы талдаудың спектрлі жүйесін толық меңгергенін, ғылыми талдаудағы білім мен біліктілік дағдысының қалыптасқанын байқаймыз. Алдағы уақытта мәтінді сөйлем деңгейінде талдауға ерекше мән беріп, оның мәтіндегі қолданысын терең талдауына ерекше көңіл аударған жөн. 


\section{С деңгейіндегі оқушы жұмысына берілген кері байланыс}

С деңгейінде жазған жұмыста оқушы мәтіннің айырмашылығы мен ұқсастығын, мазмұнын, мақсатын, аудиториясын, формасын, стилін анықтап, оған қатысты дәлелдерге жалпы сараптама жасай алған. Окушы А және Ә мәтіндері бойынша кең спектрлі талдау жасай алмаған, тек қана мәтіндердің айырмашылықтары мен ұқсастығын, мақсаты мен мазмұны, стиліне қатысты сипаттық ерекшеліктеріне ғана жалпы шолу жасаған. А мәтінінің ғылыми мақалаға Ә мәтінінің блог жазбасына қатыстылығын мәтінмен байланыстыра отырып сараптауы жеткіліксіз. Оқушы А мәтінінің ғылыми мақаладан үзінді екенін ондағы кәсіби термин сөздер («климат», «озон абать»», «ландмафт») мен жалқы есімдердің («Қытай, Чех, Үнді) мемлекеттерінің атауларын, сандық көрсеткіштерді («90,30,40 градус») мәтіндегі статистикалық мәліметтермен байланыстыра алған, олардың сипаттық ерекшеліктеріне анықтама, дәлелдемелерге негізделетініне біршама тоқталып өткен. Алдағы уақытта мәтін, сөйлем деңгейіндегі талдауларға яғни олардың мәтін мазмұнын ашудағы мақсатына, қолданысына назар аударған жөн.

\section{Е деңгейіндегі оқушы жұмысына берілген кері байланыс}

Е деңгейінде жазған оқушы жауабынан тапсырманы өте шектеулі түсінгенін, теориялық білімінің төмендігін сараптаған жұмыстарынан көруге болады. Мәтіннің түрін, жанрын, формасын, стилін ажыратуда түсінігінің таяз екендігі де байқалады. Мысалы, «А мәтінінің формасы сипаттау элементтерінен тұрады. Ал Ә мәтіні блог жазбасы. Ә мәтінінің формасы А мәтініне ұқссас сипаттау болып табылады.» деп жазуы дәлел бола алады. Сондай-ақ, оқушының мәтіннің түрін, айырмашылығын, стилін ажыратуда орынсыз әрі жүйесіз жазған жауаптарынан оқушының білімі мен түсінігінің аздығымен қатар, мәтінге ғылыми сараптама талдау дағдысының да қалыптаспағанын анық байқауға болады. Мәтінді тілдік, сөз, сөйлем тұрғыдағы талдауларына тоқталатын болсақ, мәтіндегі сөздерді құр санамалап көрсетумен шектелген, мазмұнмен сабақтастыра талданбаған. Ә мәтіні бойынша талдау мүлде шектеулі берілген, тек қана ауызекі сөйлеу стилі деп қана көрсеткен. Мәтіннің мазмұнына қатысты лексиканы сенімсіз қолданған. Орынсыз қолданған тілдік құрылымдар, жүйесіз талдаулар жиі орын алған.

Сыртқы жиынтық бағалау оқу нәтижелерін жүйелі түрде жинақтауға, қорытуға бағытталған. Кез келген бағалауды өткізу үшін оқушылардың нені білетіндігін және не істей алатындығын, сонымен қатар олар қандай қиындықтармен кездесуі мүмкін екендігін анықтау қажет. Жиынтық жұмыс жыл соңындағы оқушы білімінің жетістігін саралайды. 
Мұғалімнің оқушылар жұмысына жазған пікірлері оқу сапасының «Назарбаев Зияткерлік мектептері» ДББҰ NIS-Programme Білім беру бағдарламасы мен халықаралық стандарттардың мазмұнына сәйкестігін талдауға, оқыту әдістерінің тиімділігін арттыруға да мүмкіндік береді.

\title{
Қолданылған әдебиеттер:
}

1. Оразбаева Ф. «Тілдік қатынас». Алматы «Сөздік-Словарь», 2005 ж.

2. http://bilimdiler.kz/ustaz/4850-okushylarga-surak-koyu-zhane-olardynzhauaptaryna-karay-areket-etu-turaly.html(23.09.2014)

3. «Назарбаев Зияткерлік мектептері» ДББҰ NIS-Programme Білім беру бағдарламасы, Нұр-Сұлтан, 2019 ж.

\section{FORMATION OF INTEREST IN THE CREATIVE PROCESS OF EDUCATIONAL AND COGNITIVE ACTIVITY THROUGH EXTRACURRICULAR ACTIVITIES}

Ayshe Tashbaeva Teacher of the municipal budgetary educational institution "Amurskaya school", Russia, v. Amurskoye

\section{ФОРМИРОВАНИЕ ИНТЕРЕСА К ТВОРЧЕСКОМУ ПРОЦЕССУ УЧЕБНО-ПОЗНАВАТЕЛЬНОЙ ДЕЯТЕЛЬНОСТИ ПОСРЕДСТВОМ ВНЕУРОЧНОЙ ДЕЯТЕЛЬНОСТИ}

\author{
Ташбаева Айше Сияровна \\ учитель мунищипального бюджетного \\ общеобразовательного учреждения «Амурская школа», \\ $P \Phi$, с. Амурское
}

Переход российского образования на новые федеральные государственные образовательные стандарты неразрывно и непрерывно связан с повышением информатизационного уровня всей системы образования, так называемому понятию информационной грамотности, так как современное информационное общество предъявляет высокие требования. 
Сегодня в первую очередь учитывается реальность и тенденции нынешнего образования. Современные дети живут и развиваются в эпоху информатизации. В условиях динамичной, быстро меняющейся жизни от них требуется не только усвоение знаний и владение ими, но и в первую очередь умение добывать эти знания самим, мыслить самостоятельно и творчески. Мы хотим видеть наших детей любознательными, общительными, умеющими ориентироваться в окружающей обстановке, решать возникающие проблемы, самостоятельными, творческими личностями.

Проблема формирования познавательного интереса всегда была и остаётся одной из актуальных проблем в современном образовании. От поиска её решения в значительной степени зависит эффективность учебновоспитательного процесса, поскольку познавательный интерес является и важным мотивом познавательной деятельности школьника, и, одновременно, основным средством ее оптимизации. Кроме того, познавательный интерес играет важную роль в становлении личности, при определённых условиях становится чертой личности и обнаруживает себя в любознательности, пытливости, в постоянной и неистощимой жажде знаний.

Развитие творческих способностей является приоритетным направлением в современном образовании. Актуальность данного направления, необходимость его разработки обусловлены современными тенденциями социально-экономического развития нашей страны, повышением роли человеческого фактора во всех сферах деятельности, которые предполагают наличие определенной группы способностей (специальных и творческих), необходимых для успешной реализации этой деятельности.

Для формирования познавательного интереса, развития творческих способностей использую следующие технологии во внеурочной деятельности:

- Технология сотрудничества

- Игровые технологии

- Технологии проектной и исследовательской деятельности

- Информационно-коммуникационные технологии (ИКТ)

На занятиях внеурочной деятельности воплощаются творческие замыслы педагога и творчество обучающихся, что дает возможность развивать тягу к знаниям, к образованию вообще. Практика показывает, что учебный материал со стандартных уроков забывается быстрее, чем тот, что разбирается, либо обобщается на занятиях внеурочной деятельности. В первую очередь это происходит за счет возможности более активного использования методов и приемов активизации познавательного интереса.

Существует огромное множество методов и приемов активизации познавательного интереса учащихся: уроки обобщения и систематизации 
знаний, интегрированные уроки, нетрадиционные уроки (деловые игры, уроки-соревнования и другие). Одним из средств реализации данного характера обучения являются прикладные задачи, содержание которых раскрывают возможности математики в различных областях науки, сфер, производства, быта и т.д. Следует учитывать необходимость использования достоверных числовых данных, условий, моделирующих ту или иную ситуацию окружающей действительности.

Занятия внеурочной деятельности посещают дети с разным уровнем знаний. Поэтому всегда отбираешь материал, чтобы слабым ученикам было под силу, а сильному не скучно на уроке:

5 класс - тема "Вместе строим дом "Площади";

6 класс - тема "Математика и наше питание. Отношения и пропорции";

7 класс - тема "Кто больше? Решение линейных уравнений и их систем";

8 класс - тема “Аукцион (Итоговое повторение)”;

9 класс - тема "Прогрессия вокруг нас".

Мы видим, что игровые методы включают в себя познавательнодидактические, ролевые, деловые игры. В дидактических играх изучаемый учебный материал включается в необычный игровой контекст. Они могут проводиться в виде научных, культурных, социальных явлений: конкурс знатоков, конференция "Поле чудес", в виде предметно-содержательных моделей (например, игра - путешествие, составление сказок и т.п.).

Применение информационных технологий во внеурочной деятельности способствует активизации внимания, мышления, восприятия, памяти, воображения, познавательных интересов и творческих способностей.

В свою очередь, познавательный интерес ребёнка и качество обучения определяют его полное развитие как умственное, так и физическое. Практический опыт свидетельствует, что каждый учитель может добиваться хороших качественных результатов, работая с учащимися с использованием информационных технологий на своих уроках и во внеклассной деятельности.

Сегодня роль Интернета в развитии общества чрезвычайно возросла. Интернет - это отличный и очень гибкий инструмент, позволяющий решать широкий спектр задач, где есть возможность индивидуально приобретать новые знания, работать с различными источниками информации. Мультимедийные средства нового поколения включают в себя все преимущества компьютерных технологий, так как соответствуют тому уровню восприятия информации, которым обладает нынешнее поколение учеников, выросших на телевидении, компьютерах, мобильных 
телефонах, у которого гораздо выше потребность в визуальной информации и зрительной стимуляции. Использование в процессе обучения компьютерных средств помогает заинтересовать школьника, определить область интереса, повысить умственные и развить творческие способности. Однако, в условиях неограниченного доступа к информации в выигрыше остается тот, кто способен быстро и успешно определять, находить, отбирать, оценивать информацию и применять ее для решения своих проблем. Использование ПК и различных прикладных программ позволяет автоматизировать работу и труд учителя при создании методических пособий, тем более что представление различного рода электронных учебников, учебно-методических пособий имеет ряд важных преимуществ. Во-первых, это автоматизация процесса создания таковых, так и хранения данных в любой необходимой форме. Во-вторых, это работа с практически неограниченным объемом данных. Создание компьютерных технологий в обучении соседствует с изданием учебных пособий новой генерации, отвечающих потребностям личности обучаемого.

Планирование занятия с использованием интерактивной доски предполагает большую временную нагрузку на преподавателя по подготовке материала в электронном виде. Однако есть и преимущества.

Доска способна визуально и быстро представить то, что трудно или скучно объяснять словами. Она выводит зрительную составляющую учебных процессов на более высокий уровень и помогает преподавателю, предоставляя возможность создавать динамичные уроки, которые захватывают внимание учеников. На ней можно размещать большое количество разноплановой информации, плотность которой намного выше, чем на обычной доске.

Использование компьютера в учебном процессе дает возможность накопить в банке данных необходимый учебный материал. Наличие в кабинете большого количества цифровых образовательных ресурсов (ЦОР) позволяет учителю применять их на различных этапах обучения и/или различных этапах занятия.

Применение новых информационных технологий в школе в урочной и внеурочной деятельности дает возможность значительно повысить интерес детей к учебе, а, следовательно, и улучшить качество знаний учащихся.

Главной особенностью внеурочной деятельности является то, что эта форма активности детей обусловлена в основном их интересами и потребностями, т. е. дети изначально замотивированы посещать данные занятия. Это позволяет учителю создать дополнительные условия для развития обучающихся, стимулирования их познавательного интереса. 


\section{Список литературы:}

1. Григорьев Д.В. Внеурочная деятельность школьников. Методический конструктор: пособие для учителя/Д.В.Григорьев, П.В.Степанов. - М.: Просвещение, 2010. - 223 с.

2. Внеурочная деятельность. 1-11 классы. Теория и практика. - М.: ВАКО, 2015. - 288 c. 


\title{
SECTION 3.
}

\author{
ENGINEERING
}

\section{DESIGN ENCODER FOR 14 NM PROCESS AND STUDY OF CHANGES IN PROPERTIES AS A CHANGE OF TEMPERATURE}

\author{
Armen Babayan \\ Master's student, \\ National Polytechnic University of Armenia, \\ Armenia, Yerevan
}

In the article, the development of an encoder for the $14 \mathrm{~nm}$ process and a study of changes in its parameters when heated.

Keywords: encoder, MOS, transistor, temperature, heating.

\section{Introduction}

A Priority encoder (PE) is a basic but critical unit in digitalsystems, and it has been widely used in many applications,such as fixed and floating point units, comparators, incre-menter/decrementer circuits, sequential address encoder ofcontent addressable memories and so on. In a multi-bit PE,each bit is assigned a priority weighting according to its ownposition weighting. A logic-1 priority token is initially andtemporarily given to all bits. While the bit with a higherpriority accepts a logic- 1 input, it will pass a logic-0 signalto update the priority tokens of those lower priority bits todisable their priority. Meanwhile, when any one bit acceptsa logic-0 input, it will also lose its priority by definition. Foreach input pattern, only the bit keeping the logic-1 tokencan generate a logic- 1 output, while all the other bits willget logic-0 outputs.

\section{Development of a priority encoder}

The encoder circuit is shown in diagram 1. The 8 to 3 Encoder or octal to Binary encoder consists of 8 inputs and 3 outputs. Each input line corresponds to each octal digit and three outputs generate corresponding binary code. 


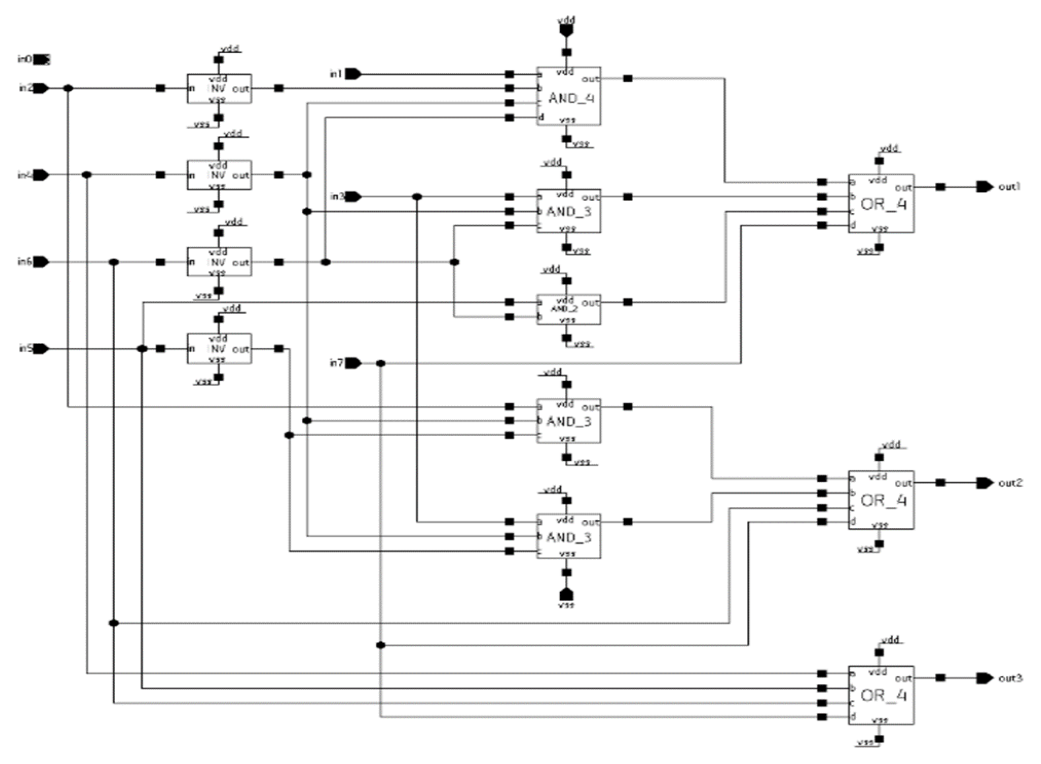

Diagram 1. Encoder

A timing description of the encoder is shown in graph 1 .

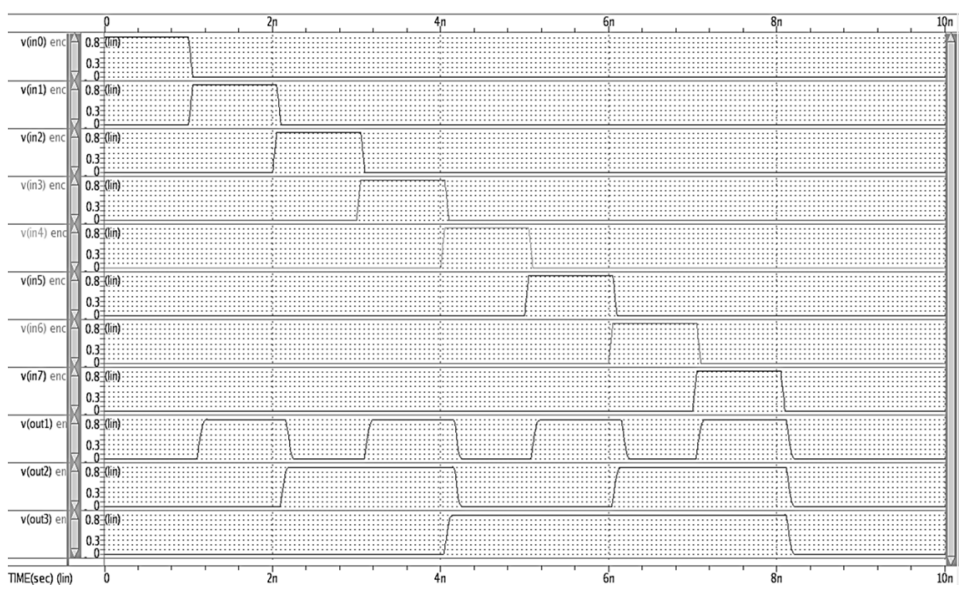

Graph 1. Temporary description of the encoder 


\section{Inspection of the encoder at different temperatures}

In further, we will use the study of changes in the parameters of the MOS transistor when heated. The main changes are changes in the threshold voltage, changes in the mobility of electrons and the saturation voltage.

Changes in the encoder description during heating are shown in graph 2.

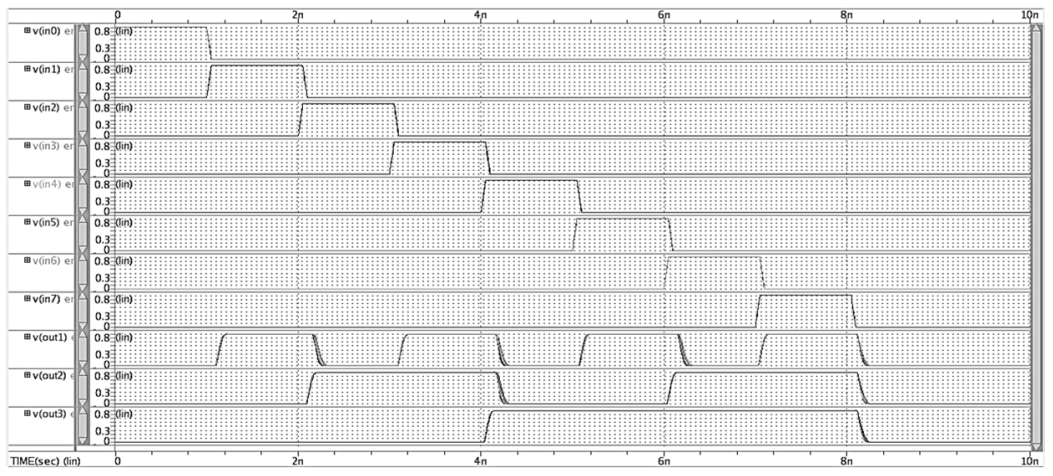

Graph 2. Temporary description of the encoder at different temperatures

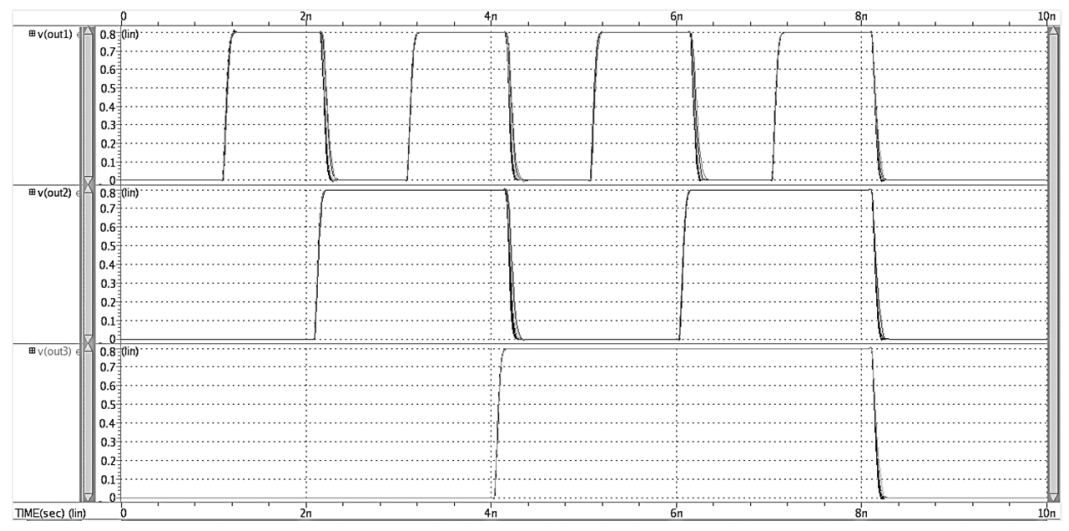

Graph 3. Detailed time description of encoder outputs at different temperaturesx 


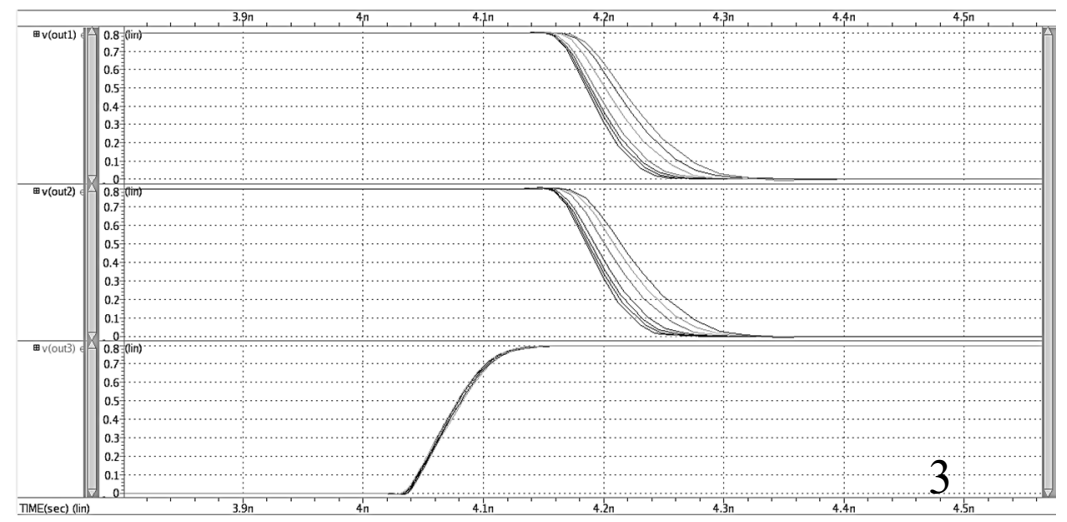

\section{Graph 4. Switching point of the encoder at different temperatures}

Graph 4 shows the switching point of the encoder in more details. As you can see from graph 3 , when encoder heated, the output signal is obtained later as the temperature rises.

\section{Conclusion}

When designing an encoder, if accuracy has the prime importance, then temperature variations must be considered.

\section{References:}

1. Wang, Xiaoyu \& Feng, Yukang. (2018). Analysis and Design of 8-Bit CMOS Priority Encoders.

2. Cheung, Tsang \& Butson, Martin \& Yu, Peter. (2004). Effects of temperature variation on MOSFET dosimetry. Physics in medicine and biology. 49. N191-6. $10.1088 / 0031-9155 / 49 / 13 / \mathrm{N} 02$.

3. GeeksforGeeks (25 Nov, 2019) Encoder in Digital Logic, Available at: https://www.geeksforgeeks.org/encoder-in-digital-logic/. 


\title{
VARIATIONS OF OPERATIONAL AMPLIFIER FREQUENCY PARAMETERS DEPENDING ON RANDOM DEVIATIONS OF THE 16NM TECHNOLOGICAL PROCESS TRANSISTORS
}

\author{
Vazgen Gevorgyan \\ Masters student,
}

National Polytechnical University of Armenia, Armenia, Yerevan

\section{ИЗМЕНЕНИЕ ЧАСТОТНЫХ ПАРАМЕТРОВ ОПЕРАЦИОННОГО УСИЛИТЕЛЯ В ЗАВИСИМОСТИ ОТ СЛУЧАЙНЫХ ОТКЛОНЕНИЙ ТРАНЗИСТОРОВ 16НМ ТЕХНОЛОГИЧЕСКОГО ПРОЦЕССА}

\author{
Геворгян Вазген Семенович \\ магистрант, \\ Национальный Политехнический Университет Армении, \\ Армения, г. Ереван
}

\begin{abstract}
АННОТАЦИЯ
В статье преведены количественные значения изменений в частотных параметрах складного каскодного операционного усилителя в зависимости от случайных отклонений транзисторов технологического процесса. Целевая сигма отклонений равна 4.5. Схема сконструирована 16 нм технологическим процессом и смоделирована для типового, быстрого и медленного процесса.

Ключевые слова: операционный усилитель, случайные отклонения, QQ график.

\section{Введение}

Интегральные схемы в настоящее время активно масштабируются, и количество элементов на единицу площади увеличивается. В современных технологических процессах длина канала транзистора достигает 3
\end{abstract}


нанометров. С уменьшением технологий отклонения технологического процесса в производстве, в процентном соотношении увеличиваются. Проблема очень актуальна и в моделированиях интегральных схем и ее частей необходимо учесть отклонения параметров транзисторов, чтобы получить более точные и правдоподобные результаты [1,2]. Эта проблема наиболее выражена в операционных усилителях, поскольку сходство двух дифференциальных ветвей критично для его правильной работы. Несходства в этих двух ветвях, по причине случайных отклонений технологического процесса, могут привести к достаточно большой деградации выходного сигнала и рабочих параметров $[3,4]$.

\section{Разработка операционного усилителя}

Разработан складной каскодный операционный усилитель с РМОП входами. Схема усилителя приведена на изображении 1. Этот тип операционных усилителей обеспечивает широкий диапазон выходного напряжения и высокий коэффициент усиления. Все напряжения смещения для транзисторов сгенерированы зеркалами тока, с одного входного источника тока (Iref). Усилитель разработан и откалиброван при выходной нагрузке в 5пФ.

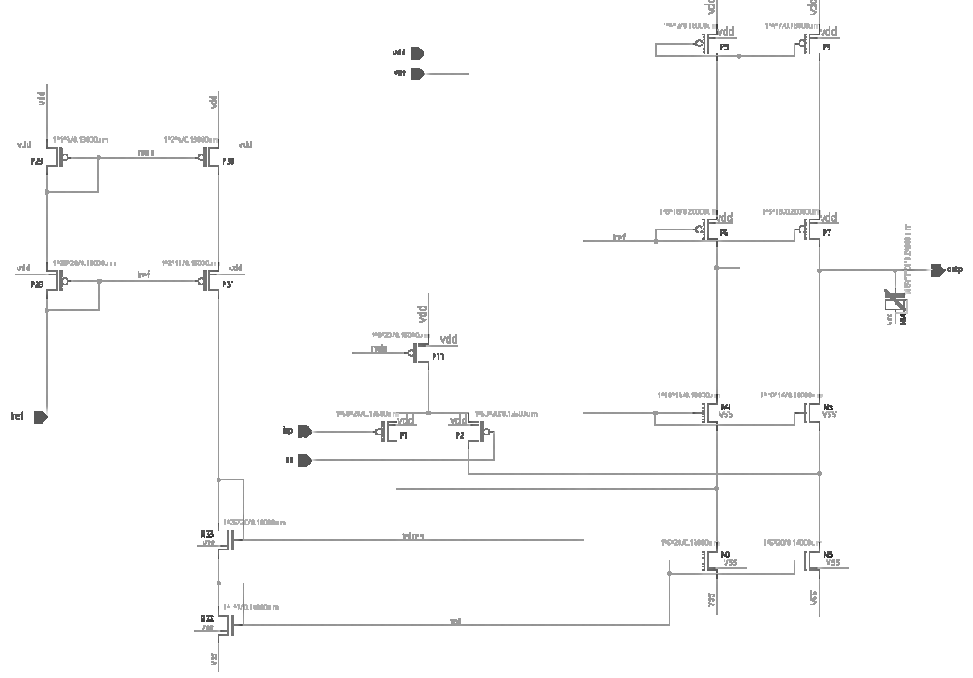

Изображение 1. Схема складного каскодного операционного усилителя 
Для определения основных рабочих параметров операционного усилителя был проведен АС анализ. Для АС анализа используется схема с обратной связью, с резистором и емкостью, приведенная на изображении 2.

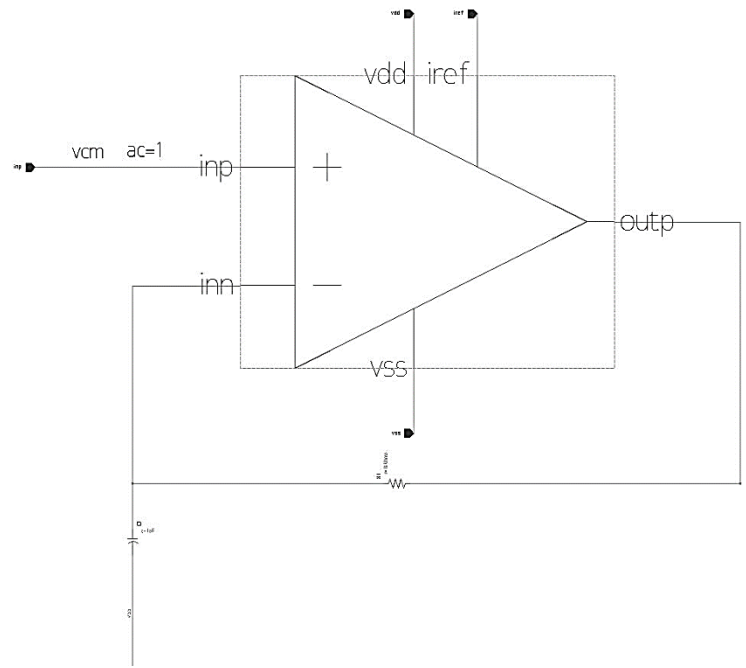

Изображение 2. Схема подключения усилителя для АС анализа

Опорный источник напряжения подключен к положительному входу операционного усилителя. Постоянная составляющая (DC) источника опорного напряжения подключена к входу $\mathrm{Vcm}$, а переменная составляющая (AC) величина равна 1 единице напряжения. Величины емкости и сопротивления, подключенных обратной связью, должны быть достаточно большими, чтобы отфильтровать переменную составляющую выходного сигнала. АС анализ выполняется от 1 Гц до 20 ГГц, по 100 измерений на декаду.

Схема сконструирована из элементов 16 нм технологического процесса, транзисторами с толстым оксидом, смоделирована программным обеспечением HSPICE [5]. Схема проверена для типового случая, а также для двух худших случаев. Входные параметры для моделирования приведены в таблице 1. 
Таблица 1.

Входные параметры для моделирования

\begin{tabular}{|c|c|c|c|c|}
\hline Процесс & $\begin{array}{c}\text { Напряжение } \\
\text { питания }\end{array}$ & Температура & $\begin{array}{c}\text { Входной ток } \\
\text { Iref }\end{array}$ & $\begin{array}{c}\text { Опорное } \\
\text { напряжение } \\
\text { Vcm }\end{array}$ \\
\hline $\mathrm{tt}$ & $1.8 \mathrm{~B}$ & $25^{\circ} \mathrm{C}$ & $20 \mathrm{M \kappa}$ & $0.95 \mathrm{~B}$ \\
\hline $\mathrm{ff}$ & $1.98 \mathrm{~B}(+10 \%)$ & $125^{\circ} \mathrm{C}$ & $20 \mathrm{M \kappa}$ & $0.95 \mathrm{~B}$ \\
\hline $\mathrm{ss}$ & $1.62 \mathrm{~B}(-10 \%)$ & $-40^{\circ} \mathrm{C}$ & $20 \mathrm{M \kappa}$ & $0.95 \mathrm{~B}$ \\
\hline
\end{tabular}

\section{Результаты моделирований}

Приведены результаты регулярного АС анализа без отклонений, откалиброванного операционного усилителя.

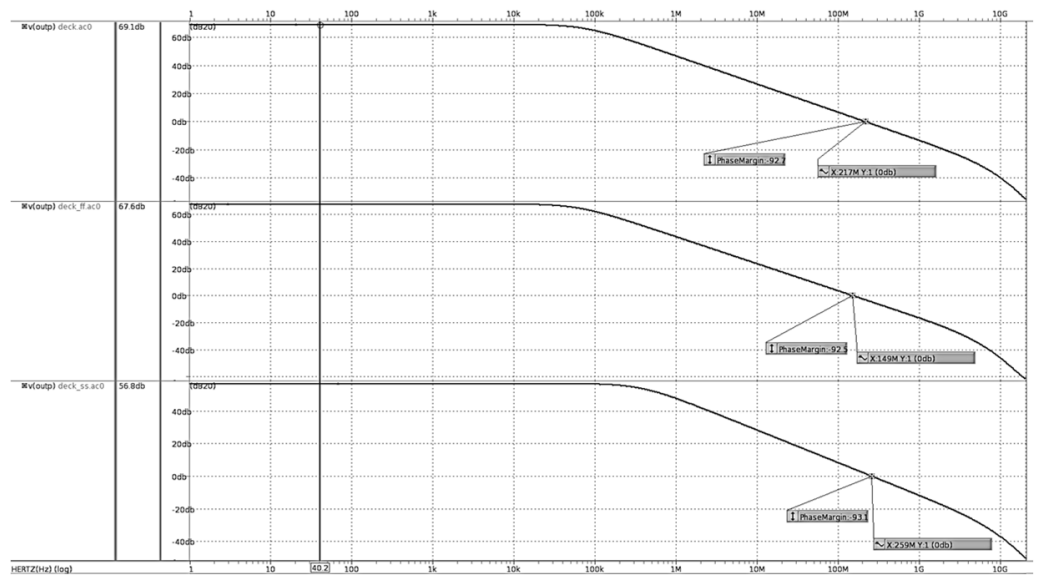

Изображение 3. Результаты моделирования без отклонений

Для расчета отклонений были использованы модели транзисторов со случайными отклонениями. Для каждого ряда входных параметров были совершены 300 моделирований. Целевая сигма равна 4.5. 

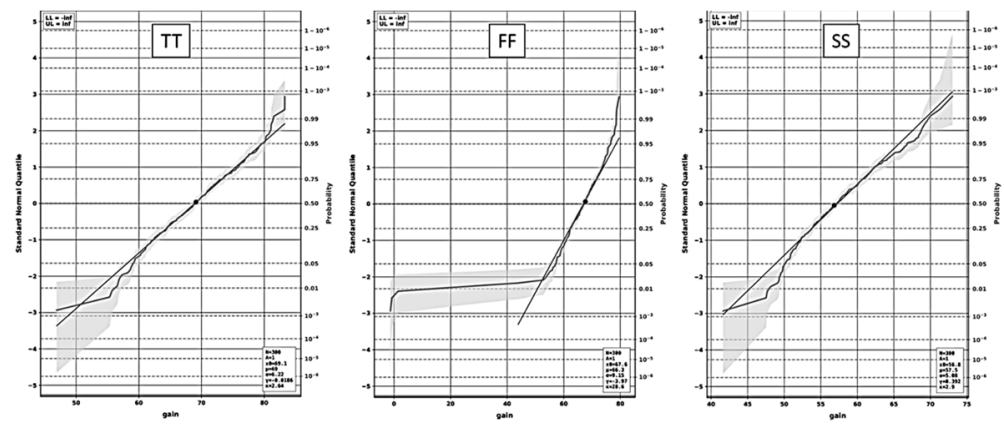

a)
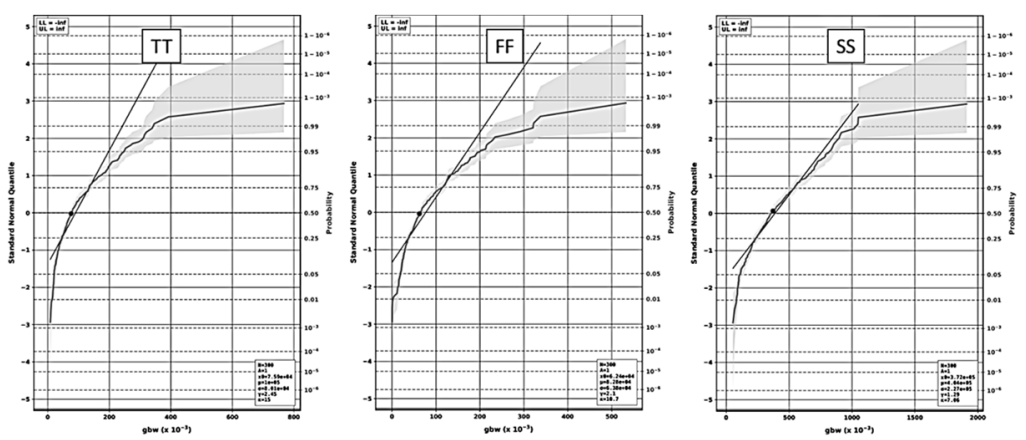

б)
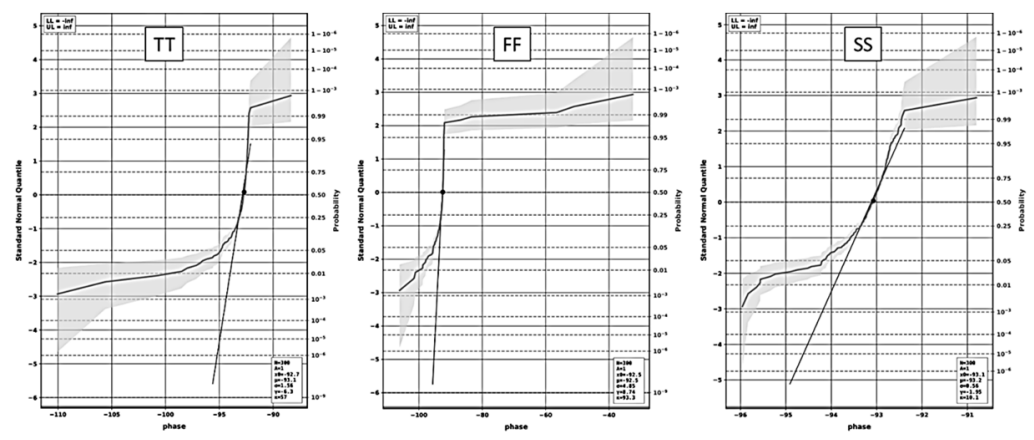

B) 

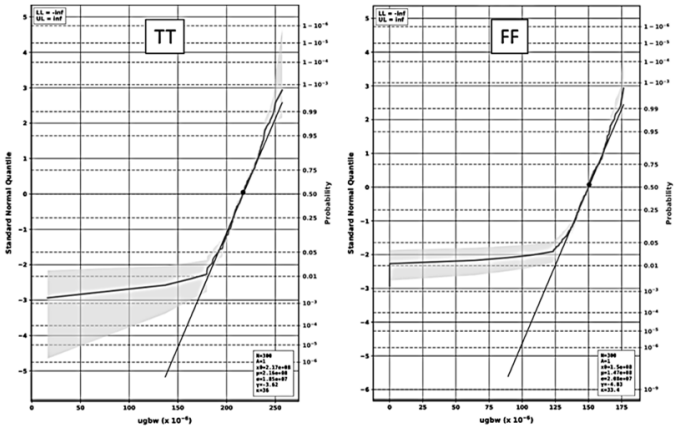

г)

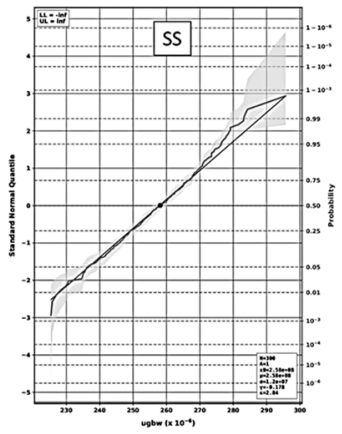

Изображение 4. $Q Q$ графики частотных параметров

На изображении 4 представлены QQ графики, которые показывают насколько: а) коэффициент усиления, б) фазовый запас, в) частотный диапазон, г) частота при 0дБ усилении операционного усилителя отклонялись во время моделирований.

В таблице 2 показаны полученные параметры без отклонений, и минимальное и максимальное значение параметра при случайных отклонениях, в пределах 4.5 сигма, для типового, быстрого и медленного процесса.

Таблица 2.

\section{Результаты моделирований}

\begin{tabular}{|c|c|c|c|c|c|c|c|c|c|c|}
\hline \multirow{3}{*}{\multicolumn{2}{|c|}{ Параметр }} & \multicolumn{3}{|c|}{$\begin{array}{c}\text { Без } \\
\text { отклонений }\end{array}$} & \multicolumn{6}{|c|}{ С отклонениями } \\
\hline & & \multirow{2}{*}{ TT } & \multirow{2}{*}{ FF } & \multirow{2}{*}{ SS } & \multicolumn{2}{|c|}{ TT } & \multicolumn{2}{|c|}{ FF } & \multicolumn{2}{|c|}{ SS } \\
\hline & & & & & Мин & Макс & Мин & Макс & Мин & Мак \\
\hline $\begin{array}{l}\text { Коэфф1 } \\
\text { усилени }\end{array}$ & дБ & 69.1 & 67.6 & 56.8 & 46.8 & 83.2 & 43.8 & 79.5 & 41.6 & 73 \\
\hline $\begin{array}{l}\text { Фазовый запас } \\
\text { (phase) }\end{array}$ & $\circ$ & 92.7 & 92.5 & 93.1 & 10 & 88.3 & 56.5 & 106.1 & 0.7 & 5.9 \\
\hline $\begin{array}{l}\text { Частотный } \\
\text { диапазон (gbw) }\end{array}$ & КГц & 759 & 62.4 & 372 & 768 & 11.5 & 532 & 11.3 & 1911 & 52.7 \\
\hline $\begin{array}{l}\text { Частота при } 0 \text { дБ } \\
\text { усилении (ugbw) }\end{array}$ & МГц & 217 & 149 & 259 & 257 & 137 & 176 & 64.1 & 296 & 225 \\
\hline
\end{tabular}

\section{Заключение}

В ходе моделирований определились количественные значения изменений в частотных параметрах складного каскодного операционного усилителя в зависимости от случайных отклонений транзисторов 
технологического процесса, при 4.5 целевой сигме. Из полученных результатов видно, что отклонения оказали большее влияние на частотный диапазон.

\title{
Список литературы:
}

1. A. MICHARD, F. CACHO, D. CELESTE and X. FEDERSPIEL, "Global and Local Process Variation Simulations in Design for Reliability approach," 2019 IEEE 25th International Symposium on On-Line Testing and Robust System Design (IOLTS), Rhodes, Greece, 2019, pp. 72-75.

2. R. Singh, K. Aditya, A.K. Bansal, P.A. Chanawala, T.B. Hook and A. Dixit, "7$\mathrm{nm}$ Nanowire FET process variation modeling using industry standard BSIMCMG model," 2016 3rd International Conference on Emerging Electronics (ICEE), Mumbai, India, 2016, pp. 1-4.

3. B. Razavi Design of Analog CMOS Integrated Circuits. - Second Edition. McGraw-Hill, 2015. -782 p.

4. A.S. Sedra, K.C. Smith Microelectronic Circuits. - Oxford University Press, 2014. $-1397 \mathrm{p}$.

5. Hspice Application Manual, Synopsys Inc. - 2010. - 196 p.

\section{USE OF LOCAL NETWORK PREVENTION METHODS OF ENTERPRISES AND ORGANIZATIONS BASED ON DLP TECHNOLOGY (DATA LEAK PREVENTION)}

\author{
Aisultan Kharakozha \\ 2nd year undergraduate student, \\ Eurasian National University.L.N. Gumilyov, \\ Kazakhstan, Nur-Sultan \\ V.A. Kobzarev \\ Ph.D. of Engineering Sciences, senior lecturer \\ Eurasian National University.L.N. Gumilyov, \\ Kazakhstan, Nur-Sultan
}




\title{
ИСПОЛЬЗОВАНИЕ МЕТОДОВ ПРЕДОТВРАЩЕНИЯ УТЕЧКИ ИНФОРМАЦИИ ЛОКАЛЬНЫХ СЕТЕЙ ПРЕДПРИЯТИЙ И ОРГАНИЗАЦИИ НА ОСНОВЕ TЕХНОЛОГИИ DLР (DATA LEAK PREVENTION)
}

\author{
Харақожа Айсұлтан \\ Магистрант 2-го курса, \\ Евразийский национальный университет им. Л.Н. Гумилева, \\ Республика Казахстан, г. Нур-Султан \\ Кобзарев В.A. \\ канд. техн. наук, ст. преподаватель, \\ Евразийский национальный университет им. Л.Н. Гумилева, \\ Республика Казахстан, г. Нур-Султан
}

\begin{abstract}
Incidents involving data breaches have been ever-present in the media for several years. In order to overcome this threat, organizations apply enterprise content-aware data leakage prevention (DLP) solutions to monitor and control data access and usage. This article reviews main principles of the DLP technology and further observations on embedding this technology in several organizations.

\section{АННОТАЦИЯ}

Инциденты, связанные с утечкой данных, постоянно появляются в СМИ на протяжении нескольких лет. Чтобы преодолеть эту угрозу, организации применяют решения по предотвращению утечки данных (DLP) для мониторинга и контроля доступа к данным и их использования

В этой статье рассматриваются основные принципы технологий DLP, а также следующие наблюдения и основные нюансы, которые были обнаружены после внедрения этой технологии в некоторых организациях.

Keywords: data leak, monitoring, access control, organizations.

Ключевые слова: утечка данных, мониторинг, контроль доступа, организации.

Организации обрабатывают и сохраняют множество конфиденциальных данных, таких как коммерческая тайна, данные клиентов, прайслисты, алгоритмы и планы приобретения. Эти данные могут быть украдены недобросовестным конкурентом, организованной преступной группой и другими объектами через множество каналов, включая электронную почту, Интернет, портативные устройства хранения и
\end{abstract}


облачные сервисы. Утечка данных может обойтись дорого, нанести вред бренду и репутации организации и подорвать доверие. Клиенты и акционеры ожидают, что организации примут соответствующие меры для надлежащей защиты их данных и инвестиции. Успешная программа предотвращения утечки информации (DLP) может значительно снизить эти риски.

Предотвращение утечки информации (Data Leak Prevention) - это набор инструментов и процессов, используемых для защиты конфиденциальных данных от потери, неправильного использования или доступа неавторизованных пользователей. Программное обеспечение DLP классифицирует регулируемые, конфиденциальные и критически важные для бизнеса данные и выявляет нарушения политик, определенных организациями или в рамках заранее определенного пакета политик, обычно обусловленных соблюдением нормативных требований, таких как HIPAA, PCI-DSS или GDPR. Как только эти нарушения обнаружены, DLP обеспечивает исправление с помощью предупреждений, шифрования и других защитных мер, чтобы предотвратить случайный или злонамеренный обмен данными конечными пользователями, которые могут поставить организацию под угрозу. Программное обеспечение и инструменты для предотвращения потери данных отслеживают и контролируют действия конечных точек, фильтруют потоки данных в корпоративных сетях и отслеживают данные в облаке для защиты данных в состоянии покоя, в движении и использовании. DLP также предоставляет отчеты, чтобы соответствовать требованиям и требованиям аудита, а также выявлять слабые места и аномалии для криминалистической экспертизы и реагирования на инциденты.

Для мониторинга и управления потоком конфиденциальных данных инструмент DLP настраивается с использованием технической политики DLP. Политика DLP содержит одно или несколько правил, состоящих из условия, исключения и действия, против которых данные, файлы, содержимое документа, сообщения оцениваются для обнаружения и предотвращения утечек данных. С помощью политик DLP организации могут определять:

- какие данные можно и нельзя отправлять, публиковать, загружать, перемещать или копировать и вставлять;

- куда можно передавать данные;

- кто может отправлять и получать данные;

- как можно обмениваться данными.

Утечка данных в виде электронных файлов не означает, что исходные данные теряют свою форму или содержание. Если электронный файл попадает в руки злоумышленникам, организации будет сложно определить, 
что произошла утечка информации. Статистика EKRAN показывает, что более $40 \%$ организаций требуется несколько лет для обнаружения утечек данных, связанных с внутренними угрозами [6].

Чтобы свести к минимуму возникновение инцидентов утечки информации и ущерб от них, организации в настоящее время пытаются разработать и внедрить различные технологии безопасности. Есть много видов технологий безопасности, которые сложно классифицировать, поскольку многие из них выполняют ключевые функции, которые частично совпадают. Технологии безопасности можно подразделить на технологию контроля утечек, которая предоставляет ответственность перед пользователями и технология контроля доступа, ограничивающая доступ пользователей. Обнаружение инцидентов безопасности благодаря непрерывному мониторингу включает в себя технологию, которая обнаруживает ненормальное поведение и постоянно отслеживает и фильтрует контент, создаваемый и передаваемый в бизнесе. Эти технологии безопасности также способны управлять и обнаруживать поведение пользователя и каждого терминала, а также поведение через ненадежные каналы.

Есть несколько теорий в области ИБ и особенно ИТ-безопасности, например, неполнота Курта Гёделя [1], теорема Алана Тьюринга об остановке [2] и теорема Райса-Шапиро [3], которая доказывает, что ИТбезопасность - это вопрос вероятности. Кроме того, академические исследования постоянно демонстрируют случаи, когда данные или угечку информации невозможно предотвратить. Группа исследователей, например, недавно продемонстрировала, что это даже возможно

- для извлечения данных из изолированных систем с воздушными зазорами с помощью

- их тепловыделения [4]. Таким образом, различные утечки данных неизбежный.

Решающий ключевой фактор в сфере ИБ в организациях это человеческий фактор. Люди вводят знания в организации и создают нематериальные и материальные активы используя данные, информацию и знания. В контексте

DLP и ILP, люди должны оценить ценность нематериальных активов. Кроме того, люди правильно или неправильно определяют ценность данных, информации и знаний защиты, они рассчитывают риски безопасности, они принимают соответствующие меры безопасности на основе оценки риска они определяют правила, и они соблюдают или не соблюдают эти правила. Организация может попытаться заставить своих сотрудников соблюдать эти правила с использованием механизмов контроля, наблюдения, и мониторинг. Но этот подход доказал свою 
неэффективность в нескольких случаях, таких как инцидент с Эдвардом Сноуденом [5]. Решения DLP и ILP, а также другие технологии наблюдения, такие как системы предотвращения вторжений (IPS) и системы обнаружения вторжений (IDS), показывают некоторые недостатки, особенно когда речь идет о скрытых или подсознательных каналах и стеганографии. Более того, люди могут непреднамеренно или намеренно допустить утечку данных, информации и знаний через широкий спектр технологических и нетехнологических систем связи. В связи с тем, что не существует метода, который никогда не допускал отказа, чтобы предотвратить утечку и чтобы предотвратить как можно больше инцидентов, организация полагается на сотрудничество своих сотрудников. Результаты различных исследований, например [6], указывают, что сотрудники готовы принять компьютеризированный мониторинг и непрерывное наблюдение и соблюдение политик ИБ и меры при определенных условиях. Согласно [6], сотрудники требуют информацию о записанных данных, они предпочитают данные, не относящиеся к отдельным лицам, они ожидают ограничения доступа к этим данным, и они обеспокоены проектирование и внедрение системы видеонаблюдения. Кроме того, результаты, представленные в [6], указывают на сильную положительную корреляция между отношением и намерениями пользователей к использованию решений IS, знания пользователей и опыт пользователей с этими решениями. Поэтому различные факторы, такие как полезная безопасность, негативное отношение к механизмам контроля, а также правила конкретной страны, должны быть рассмотрены, чтобы гарантировать принятие и сотрудничество сотрудников.

В контексте ИГ абсолютная уверенность в механизмах контроля, мониторинга и наблюдения считается рискованным. Анализ обнаруженных утечек данных в 2014 г. демонстрируют, что только часть утечек данных связанные с инсайдерами были непреднамеренными. Учитывая, что администраторы систем ИТ-безопасности и обычные пользователи с соответствующими знаниями способны вызвать утечки данных, выгоднее ожидать "самого умного предполагаемого злоумышленника" (SAA) ". Чтобы получить дополнительные знания об утечках данных, эта работа предлагает расширенные критерии для характеристики инцидентов утечки данных, а также некоторых критерии для характеристики актуальности атак. Они доказывают

чтобы быть полезным инструментом для обозначения значимости успешных мер по обеспечению ИБ и выявления слабых мест. Анализ инцидентов утечки данных на основе этих расширенных критериев иллюстрируют, что человеческий фактор является решающим ключевым фактором в объем ИС. Организации полагаются на принятие и 
сотрудничество их сотрудников, потому что не существует надежного метода предотвращения утечки. Кроме того, государство передовых решений DLP с поддержкой корпоративного контента не могут надежно защитить информационные активы. Это связано с тем, что что эти решения зависят от определенных мер ИБ, которые должны быть установлены, чтобы снизить риск технологически обоснованных данных нарушения.

Таким образом, эта работа вводит последовательную концепцию, состоящую из различных элементов для установления DLP и ILP в рамках ИС.

\section{Список литературы:}

1. K. Gödel, "Über formal unentscheidbare Sätze der Principia Mathematica und verwandter Systeme I," Monatshefte für Mathematik und Physik, vol. 38, no. 1, pp. 173-198, 1931.

2. A.M. Turing, "On computable numbers, with an application to the Entscheidungsproblem,' in Proceedings of the London Mathematical Society, 1936, vol. 42. no. 2, pp. 230-265.

3. H.G. Rice, "Classes of recursively enumerable sets and their decision problems," Trans. Amer. Math. Soc., vol. 74, no. 2, pp. 358-366, 1953.

4. M. Guri, M. Monitz, Y. Mirski, and Y. Elovici. (Mar. 2015). "BitWhisper: Covert signaling channel between air-gapped computers using thermal manipulations." [Online]. Available: http://arxiv.org/ abs/1503.07919.

5. G. Greenwald, E. MacAskill, and L. Poitras, "Edward Snowden: The whistleblower behind the NSA surveillance revelations," Guardian, Jun. 2013.

6. R.A. Grant and C.A. Higgins, "Computerized performance monitors: Factors affecting acceptance,” IEEE Trans. Eng. Manag., vol. 38, no. 4, pp. 306-315, Nov. 1991. 


\title{
DEPENDENCY MANAGEMENT AND BUILD TOOLS IN JAVA
}

\author{
Narek Naltakyan \\ Student, \\ National Polytechnic University of Armenia, \\ Armenia, Erevan
}

\section{УПРАВЛЕНИЕ ЗАВИСИМОСТЯМИ И ИНСТРУМЕНТЫ СБОРКИ В JАVA}

\author{
Налтакян Нарек Левонович \\ студент \\ Национального Политехнического Университета Армении, \\ Армения, г. Ереван
}

\begin{abstract}
АННОТАЦИЯ
Использование инструментов сборки и систем стало необходимостью в мире программирования в настоящее время. Без них увеличивается время программирования и стоимость программного обеспечения, потому что без этих инструментов, которые выполняют работу автоматически, программист должен создать свой код вручную. В языковом мире Java существуют различные типы инструментов, каждый из которых имеет свои преимущества и недостатки. В этой статье мы обсудим три самых популярных из этих инструментов. Это соответственно Ant, Maven и Gradle.
\end{abstract}

Ключевые слова: инструменты сборки, Gradel, Maven, Ant:

Важность инструментов сборки и систем очень высока в современном мире технологий, особенно для программистов Јava, потому что без системы сборки когда-то приходилось вручную создавать коды программного обеспечения, которые мы используем в нашей повседневной жизни. Это привело бы ко времени программирования и стоимости программного обеспечения. В этой статье мы обсудим те инструменты, которые предназначены для создания Java. C течением времени они завоевали рынок и теперь мы можем сказать, что весь мир Јava построен с помощью этих 3 инструментов. Эти инструменты - Ant, Mavne l. Gradle. 


\title{
Проблемы касающиеся инструментов сборки
}

Перед инструменты сборки и систем стоят следующие задачи: они должны автоматизировать процесс преобразования кода программного обеспечения в выполнимый файл. Этот процесс состоит из нескольких этапов.

1. Загрузка зависимостей

2. Компиляция исходный код в двоичный код

3. Упаковка этого двоичного кода

4. Запуск тестов

5. Развертывание производственных систем

\section{Инструменты решения}

В настоящее время инструментами для сборки всемирно известного Java являются Ant, Maven l. Gradlde.

\begin{abstract}
Ant
Apache ANT (Another Neat Tool) - проект Apache с открытым исходным кодом, выпущенный в 2000 году. Это јаvа библиотека, используемая для автоматизации процессов сборки јаvа-приложений. Кроме того, он может быть использован для создания не Јava приложений. Он следует принципу "Конфигурация над конвенцией". B Ant различные этапы процесса сборки называются «Цели». Файлы сборки ANT написаны в XML, и по конвенции они называются ".xml". Он содержит три элемента: проект, цель и задача. Каждый файл сборки содержит один проект. Каждая вещь в сборке .xml находится под элементом проекта. Проект содержит по крайней мере одну цель (по умолчанию). Цель содержит набор задач внутри него. Задача - это часть кода, которую можно выполнять. Каждый узел может иметь атрибуты, связанные с ними:

Атрибуты проекта:

- Название: Название проекта.

- Basedir: Корневая папка для проекта, и она необязательна.

- По умолчанию: цель по умолчанию для сборки. Проект может иметь одну или несколько целей. Он используется для указания цели проекта по умолчанию.

Атрибуты цели:

- Имя: Имя цели.

- Описание: Описание цели.

- Зависит: Список всех целей, разделенных запятой, от которых зависит эта цель.
\end{abstract}


- Если: Цель выполняется, если атрибут соответствует действительности.

- Если только: цель не выполняется, если атрибут не установлен. Build.xml пример:

$<$ ?xml version="1.0"? $><$ project $>\quad<$ target name="armenia" $>$ $<$ echo $>$ Hello, Armenia $<$ /echo $><$ target $><$ project $>$

Добавляйте зависимость в Ant:

$<$ dependency org="org.projectlombok" name="lombok" $\mathrm{rev}=" 1.18 .10 " />$

Основным преимуществом Ant является его гибкость. Ant не навязывает разработчику какие-либо конвенции о кодировании или структуре проекта. Следовательно, это означает, что Ant требует от разработчиков писать все команды самостоятельно. Это иногда приводит к большим файлам сборки и их трудно поддерживать. Первоначально Ant не имел встроенной поддержки управления зависимостью. Позже он принял Apache Ivy, разработанный как подпроект проекта Apache Ant, с целью управления зависимостью.

\section{Apache Maven}

Это управление зависимостью и инструмент автоматизации сборки, выпущенный в 2004 году. Он продолжает использовать XML, но преодолевает недостатки, следуя принципу "Конвенция над конфигурацией". Он опирается на конвенции и предоставляет предопределенные команды (цели). Его файл конфигурации, содержащий инструкции по управлению сборкой и зависимостью, по конвенции называется "pom.xml" и присутствует в корневой папке проекта.Maven двигатель принимает pom.xml и проект в качестве входных данных. Он читает файл pom.xml и загружает упомянутые в нем зависимости в качестве файлов банки в локальный репозиторий. Затем он выполняет жизненные циклы, строит фазы и плагины. В конце концов, упакованный и проверенный артефакт генерируется.pom.xml пример: $<$ ?xml version="1.0" encoding="UTF-8"?>

xmlns="http://maven.apache.org/POM/4.0.0"

$<$ project

xmlns:xsi="http://www.w3.org/2001/XMLSchema-instance"

xsi:schemaLocation="http://maven.apache.org/POM/4.0.0

https://maven.apache.org/xsd/maven-4.0.0.xsd">

$<$ modelVersion $>4.0 .0<$ /modelVersion $>$

$<$ parent $>$ $<$ groupId $>$ org.springframework.boot $<$ groupId $>\quad<$ artifactId $>$ spring-bootstarter-parent $</$ artifactId $>$ $<$ version $>$ 2.2.5.RELEASE $</$ version $>$ $<$ relativePath $/>\quad<$ parent $>$ $<$ groupId $>$ com.example $<$ /groupId $>$ $<$ artifactId $>$ demo $</$ artifactId $>$ $<$ version $>0.0 .1$-SNAPSHOT $<$ /version $>$ 
$<$ name $>$ demo $<$ name $><$ description $>$ Demo project for Spring Boot $</$ description $>\quad<$ properties $>\quad<$ java.version $>1.8</$ java.version $>$ $<$ properties $>\quad<$ dependencies $>$ <ependency $>$ $<$ groupId $>$ org.projectlombok $<$ /groupId $>\quad<$ artifactId $>$ lombok $<$ /artifactId $>$ $<$ optional $>$ true $<$ /optional $></$ dependency $></$ dependencies $><$ /project $>$

Некоторые важные теги в pom.xml: проект.

- groupId: Она представляет организацию, которой принадлежит

- artifactId: Это название проекта.

- версия: Он представляет версию проекта.

- упаковка: Она представляет собой окончательную форму сборки проекта. например.jar, война.

Добавить зависимость в maven:

$<$ dependency $>$

$<$ artifactId $>$ lombok $<$ /artifactId $>$

$<$ groupId $>$ org.projectlombok $<$ groupId $>$ $<$ version $>1.18 .10</$ version $></$ dependency $>$

Репозиторий Maven:

Репозиторий представляет собой хранилище ресурсов, где все упакованные файлы существуют вместе с их собственными файлами пом. Эти файлы рот содержат внешние зависимости этого проекта. Таким образом maven загружает зависимость зависимостей от вашего проекта повторно до тех пор, пока все необходимые зависимости не будут присутствовать в локальном репозитории. Есть три типа репозиториев в maven:

- Локальный репозиторий: Это репозиторий, присутствующий на самой машине разработчика.

- Уровень организации/удаленный репозиторий: это репозиторий, присутствующий в организации.

- Центральный репозиторий: Это репозиторий через Интернет, созданный и поддерживаемый maven сообщества.

Всякий раз, когда зависимость указана в pom.xml проекта, maven ищет ее в локальном репозитории. Если он не найден там, он ищет его в удаленном / org широкий репозиторий. Если его нет даже там, то он ищет его в центральном репозитории.Maven предписывает строгую структуру проекта, в то время как Ant обеспечивает гибкость и там.

Недостатки maven:

- Управление зависимостями не очень хорошо справляется с конфликтами между различными версиями одной библиотеки.

- Настройка целей трудно. 


\section{Gradle}

Это инструмент управления зависимостью с открытым исходным кодом и автоматизации сборки, выпущенный в 2012 году. Он сочетает в себе хорошие части Apache Ant и Apache Maven и строит на них. Использует домен конкретный язык (на основе Groovy) вместо XML. Оно приняло гибкость от Ant и своего жизненного цикла от Maven. Он также следует принципу "Конвенция над конфигурацией". Он поддерживает хранилище Maven и Ivy для извлечения зависимостей. Его файл конфигурации по конвенции известен как "build.gradle" и присутствует в корневой папке проекта. Gradle дал своим шагам сборки название «задачи». Google принял Gradle в качестве инструмента сборки по умолчанию для OC Android.Gradle не использует XML. Вместо этого, он имел свой собственный домен специфический язык, основанный на Groovy (один из языков JVM). В результате, скрипты сборки Gradle, как правило, гораздо короче и яснее, чем те, которые написаны для Ant или Maven. Количество шаблонного кода значительно меньше с Gradle.

Конфигурации Gradle:

- implementation: Он используется для объявления зависимостей, которые мы не хотим подвергать времени компиляции наших потребителей.

- api: Он используется для объявления зависимостей, которые являются частью нашего API, т.е. для зависимостей, которые мы явно хотим подвергать нашим потребителям.

- compileOnly: Это позволяет нам объявлять зависимости, которые должны быть доступны только во время компиляции, но не нужны во время выполнения. Примером использования этой конфигурации является аннотация процессора, как Lombok, который изменяет bytecode во время компиляции. После компиляции это больше не нужно, поэтому зависимость недоступна во время выполнения.

- runtimeOnly: Это позволяет нам объявлять зависимости, которые не нужны во время компиляции, но будут доступны во время выполнения. Примером может быть SLF4J, где мы включаем slf4j-арі в конфигурацию реализации и реализацию этого API (например, slf4j-log4j12 или logback-classic) в конфигурацию runtimeOnly.

- TestImplementation: Похож на реализацию, но зависимости, объявленные с тест-имплементацией, доступны только во время компиляции и времени выполнения тестов. Мы можем использовать его для объявления зависимостей от программ тестирования, таких как JUnit или Mockito, которые нам нужны только в тестах и которые не должны быть доступны в производственном коде.

- testCompileOnly: Похожи на компиляцию, но зависимости, 
объявленные c testCompileOnly, доступны только во время компиляции тестов, а не во время выполнения.

- testRuntimeOnly: Похож на время выполнения, но зависимости, объявленные c testRuntimeOnly, доступны только во время выполнения тестов, а не во время компиляции.

build.gradle пример:

plugins \{ id 'org.springframework.boot' version '2.2.5.RELEASE' id 'io.spring.dependency-management' version '1.0.9.RELEASE' id 'java'\}group $=\quad$ 'com.example'version $=$ '0.0.1SNAPSHOT'sourceCompatibility $=$ '1.8'repositories $\{$ mavenCentral()\}dependencies $\{$ implementation 'org.springframework.boot:spring-boot-starter' $\}\}$

Добавить зависимость в Gradle:

compile group: 'org.hibernate', name: 'hibernate-core', version: '3.6.7.Final' Преимущества:

- Он обрабатывает транзитные зависимости очень хорошо. Если в проекте существует противоречивая транзитная зависимость, то для ее устранения она выбирает последнюю версию зависимости. Например, зависимость 'A' внутренне требует зависимости ' $\mathrm{C}$ ' с версией 2.0, а зависимость 'B' внутренне требует зависимости 'C' с версией 3.0. Затем Градл будет использовать последнюю версию зависимости 'С'.

- Файлы конфигурации Gradle меньше по размеру и чище, поскольку он использует доменный язык, основанный на Groovy вместо XML.

- Gradle использует концепцию инкрементной сборки и избегает работы, отслеживая входные данные и вывод задач и выполняя только то, что необходимо, и только обработку файлов, которые изменились, когда это возможно, и, следовательно, выполняет быстрее, чем maven.

Заключение.

В наши дни инструменты сборки необходимы. Надо хорошо знать, как их устройство, так и принципы их работы, чтобы выбрать подходящий инструмент не составляло труда. Язык программирования Јava развивается и приобретает новые инструменты для сборки. Эти три инструмента в настоящее время присутствуют на рынке, но рынок меняется и эта тройка может измениться за короткое время.

\section{Список литературы:}

1. https://ant.apache.org/.

2. https://maven.apache.org/.

3. https://gradle.org/. 


\title{
DESIGN PATTERNS IN PROGRAMMING
}

\author{
Aghasi Seyranyan \\ Student, \\ National Polytechnic University of Armenia, \\ Armenia, Erevan
}

\section{ПАТТЕРНЫ ПРОЕКТИРОВАНИЯ В ПРОГРАММИРОВАНИИ}

\author{
Агаси Сейранян Тадевоси \\ студент \\ Национального Политехнического Университета Армении, \\ Армения, г. Ереван
}

\begin{abstract}
Паттерн проектирования дает конкретный метод возведения программы для заключения нередко сталкивающихся задач проектирования. В предоставленном случае ожидается, собственно, что есть кое-какой комплект совокупных формализованных задач, с которыми достаточно нередко сталкиваются программисты, и паттерны дают ряд возможностей для решения данных задач. Собственно что же выделяет нам использование паттернов? При написании программ возможно формализовать делему в облике объектов и классов и связей меж ними. И можно использовать паттерн для ее заключения. В результате не надо изобретать велосипед. Уже есть готовый шаблон, и надо лишь его использовать в определенной программе. При этом паттерны, как правило, не находятся в зависимости от языка программирования. Их основы использования станут подобны и в С\#, и в Python, и в Jave, и в иных языках. Но надо понимать, что не стоит использовать паттерны из-за самих паттернов. Код хорошего программиста подразумевает внедрение паттернов. Впрочем, не всякий раз паттерны делают лучше и упрощают программу. Неоправданное их внедрение имеет возможность привести к затруднению программного кода, к увеличению размера программного кода, к сокращению его свойства. Паттерн обязан быть оправданным и действенным методикой заключения проблемы. Есть большое количество всевозможных паттернов, которые решают различные трудности и делают всевозможные задачи. Но по собственному деянию их возможно совместить в ряд групп. В базу систематизации ведущих паттернов положена цель или же задачи, которые конкретный паттерн выполняет.
\end{abstract}


Порождающие паттерны (Creational patterns) в разработке программного обеспечения порождающие паттерны - это шаблоны проектирования, которые имеют дело с механизмами создания объектов, пытаясь создавать объекты способом, подходящим для ситуации. Базовая форма создания объекта может привести к проблемам дизайна или усложнению дизайна. Порождающие паттерны решают эту проблему, каким-то образом управляя созданием этого объекта.

1. Builder (Строитель)

2. Abstract Factory (Абстрактная фабрика)

3. Prototype (Прототип)

4. Factory Method (Фабричный метод)

5. Singleton (Одиночка)

Структурные паттерны (Structural patterns) - рассматривают, как можно с помощью классов и объектов образовать более крупные объекты более сложные по характеру объекты и классы. К таким шаблонам относятся:

1. Bridge (Мост)

2. Facade (Фасад)

3. Decorator (Декоратор)

4. Adapter (Адаптер)

5. Composite (Компоновщик)

6. Flyweight (Приспособленец)

7. Рrоху (Заместитель)

Паттерны поведения - В разработке программного обеспечения п Паттерны поведения - это шаблоны проектирования, которые определяют алгоритмы и взаимодействие между классами и объектами. Поступая таким образом, эти паттерны повышают гибкость в проведении этого общения. Среди подобных шаблонов можно выделить следующие:

1. Chain of responsibility (Цепочка обязанностей)

2. Command (Команда)

3. Interpreter (Интерпретатор)

4. Iterator (Итератор)

5. Mediator (Посредник)

6. Memento (Хранитель)

7. Observer (Наблюдатель)

8. State (Состояние)

9. Strategy (Стратегия)

10.Template method (Шаблонный метод)

11.Visitor (Посетитель)

Существуют и другие групи паттернов в зависимости от того, относится паттерн к классам или объектам. Есть и иные групи паттернов 
в зависимости от такого, относится паттерн к классам или же объектам. Паттерны классов обрисовывают отношения меж классами при помощи наследования. Отношения меж классами ориентируются на стадии компиляции. К этим паттернам относятся:

1. Interpreter (Интерпретатор)

2. Template Method (Шаблонный метод)

3. Adapter (Адаптер)

4. Factory Method (Фабричный метод)

Другая доля паттернов - паттерны объектов обрисовывают отношения меж объектами. Эти отношения появляются при выполнении, в следствие этого владеют большей эластичностью. К паттернам объектов относят следующие:

1. Abstract Factory (Абстрактная фабрика)

2. Builder (Строитель)

3. Prototype (Прототип)

4. Singleton (Одиночка)

5. Bridge (Мост)

6. Composite (Компоновщик)

7. Decorator (Декоратор)

8. Facade (Фасад)

9. Flyweight (Приспособленец)

10.Proxy (Заместитель)

11.Chain of responsibility (Цепочка обязанностей)

12.Command (Команда)

13.Iterator (Итератор)

14.Mediator (Посредник)

15.Memento (Хранитель)

16.Observer (Наблюдатель)

17.State (Состояние)

18.Strategy (Стратегия)

19.Visitor (Посетитель)

Как избрать необходимый паттерн? До этого всего при заключении трудности надо отметить все применяемые сути и связи меж ними и абстрагировать их от определенной ситуации. Вслед за тем надо взглянуть, вписывается ли отвлеченная конфигурация заключения задачи в конкретный паттерн. К примеру, сущность решаемой задачи состоит в разработке свежих объектов. В данном случае, вполне вероятно, стоит взглянуть на порождающие паттерны. При этом не надо сразу взять некий конкретный паттерн 1-ый, который привиделся необходимым, а взглянуть на некоторое количество схожих паттернов из одной группы, которые решают одну и ту же задачу, прои этом принципиально воспринимать значение паттерна. Один паттерн имеет много реализации, и 
чем почаще вы будете сталкиваться с данными реализациями, тем лучше вы будете понимать смысл паттерна. Но не стоит применить паттерн, в случае если вы его не осознаете, в том числе и в случае если он несомненно поможет вас в заключении задачи. Также важно держаться принципа KISS (Keep It Simple, Stupid) предохранять код программки по способности обычным и ясным. Так как значение паттернов не в усложнении кода программки, а напротив в его упрощении. Ниже представлены коекакие главные отношения меж объектами, которые несомненно помогут взять в толк связи меж сущностями при их применении в паттернах. Можно отметить некоторое количество ведущих отношений: наследование, реализация, ассоциация, композиция и агрегация.

Наследование. Наследование считается базисным принципом ООП и разрешает классу (наследнику) унаследовать перечень возможностей иного класса (родительского). Зачастую дела наследования ещё именуют генерализацией или же обобщением. Наследование определяет отношение IS A, то есть "является". К примеру:

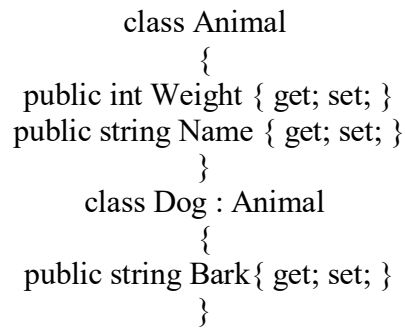

В данном случае используется наследование, а объекты класса Dog также являются и объектами класса Animal.

Реализация. Реализация предполагает определение интерфейса и его реализация в классах. Например, имеется интерфейс IMediaPlayer c методом Play, который реализуется в классе CD:

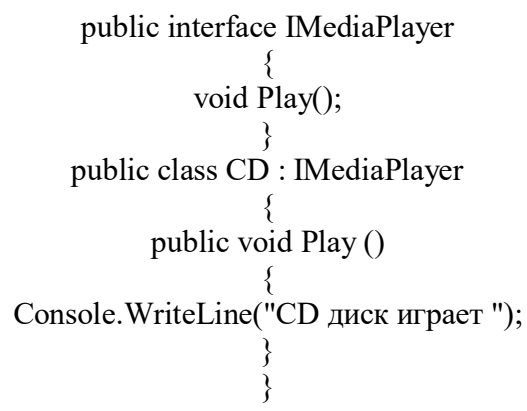


Ассоциация. Ассоциация - это отношение, при котором объекты одного типа неким образом связаны с объектами другого типа. Например, объект одного типа содержит или использует объект другого типа. Например, игрок играет в определенной команде:

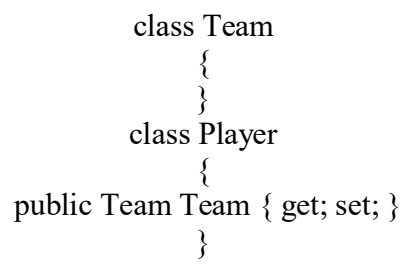

Нередко при отношении ассоциации указывается кратность связей. В данном случае единица у Team и звездочка у Player на диаграмме отражает связь 1 ко многим. То есть одна команда будет соответствовать многим игрокам. Агрегация и композиция являются частными случаями ассоциации.

Композиция. Композиция определяет отношение HAS A, то есть отношение "имеет". Например, в класс автомобиля содержит объект класса электрического двигателя:

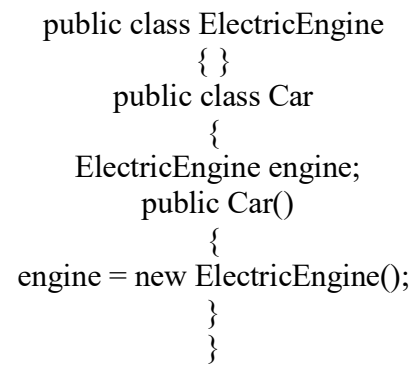

При этом класс автомобиля полностью управляет жизненным циклом объекта двигателя. При уничтожении объекта автомобиля в области памяти вместе с ним будет уничтожен и объект двигателя. И в этом плане объект автомобиля является главным, а объект двигателя - зависимой.

Агрегация От композиции следует отличать агрегацию. Она также предполагает отношение HAS A, но реализуется она иначе: 


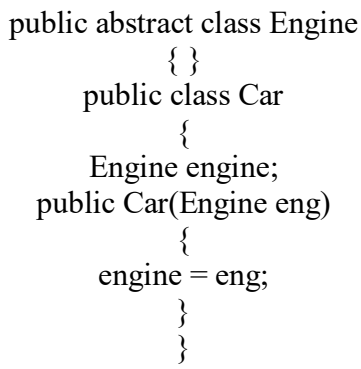

При агрегации реализуется слабая связь, то есть в данном случае объекты Car и Engine будут равноправны. В конструктор Car передается ссылка на уже имеющийся объект Engine. И, как правило, определяется ссылка не на конкретный класс, а на абстрактный класс или интерфейс, что увеличивает гибкость программы. При проектировании отношений между классами надо учитывать некоторые общие рекомендации. В частности, вместо наследования следует предпочитать композицию. При наследовании весь функционал класса-наследника жестко определен на этапе компиляции. И во время выполнения программы мы не можем его динамически переопределить. А класс-наследник не всегда может переопределить код, который определен в родительском классе. Композиция же позволяет динамически определять поведение объекта во время выполнения, и поэтому является более гибкой. Вместо композиции следует предпочитать агрегацию, как более гибкий способ связи компонентов. В то же время не всегда агрегация уместна. Например, у нас есть класс человека, который содержит объект нервной системы. Понятно, что в реальности, по крайней мере на текущий момент, невозможно вовне определить нервную систему и внедрить ее в человека. То есть в данном случае человек будет главным компонентом, а нервная система - зависимым, подчиненным, и их создание и жизненный цикл будет происходить совместно, поэтому здесь лучше выбрать композицию.

\section{Список литературы:}

1. https://metanit.com/sharp/patterns/1.2.php.

2. https://en.ppt-online.org/543071.

3. https://docplayer.ru/58449454-Metodicheskie-ukazaniya-i-zadaniya-kindividualnoy-rabote-po-discipline.html. 


\title{
THE ESSENCE AND RELEVANCE OF THE USE OF CLOUD ERP SYSTEMS
}

\author{
Aigerim Zhumanova \\ Master, International IT University, \\ Kazakhstan, Almaty \\ Vasily Serbin \\ Candidate of technical sciences, \\ associate Professor, International IT University, \\ Kazakhstan, Almaty
}

\section{СУЩНОСТЬ И АКТУАЛЬНОСТЬ ПРИМЕНЕНИЯ ОБЛАЧНЫХ ЕRР-СИСТЕМ}

\author{
Жуманова Айгерим Абдумажиткызы \\ магистрант, \\ Международный университет информационных технологии, \\ Республика Казахстан, г. Алмать \\ Сербин Василий Валерьевич \\ канд. техн. наук, ассочиированный проф., \\ Международный университет информационных технологии, \\ Республика Казахстан, г. Алмать
}

\begin{abstract}
The article discusses the essence and relevance of the use of cloud ERP systems, as well as the advantages of this system for small business in Kazakhstan.

\section{АННОТАЦИЯ}

В статье рассматривается сущность и актуальность применения облачных ERP-систем. Подчеркнуты достоинства данной системы для малого бизнеса Казахстана.
\end{abstract}

Keywords: ERP system, SaaS, cloud services.

Ключевые слова: ERP-система, SaaS, облачные сервисы.

Казахстан является одним из лидеров экономического роста на 
территории СНГ. Предприятия растут и развиваются, но методы управления не успевают за их развитием. Для многих компаний актуальными становятся задачи повышения эффективности бизнес-процессов, снижения издержек, оптимизации поставок, оперативного получения управленческой и финансовой отчетности, управления качеством продукции и ремонта оборудования. Общепринятой практикой для решения подобных задач является установка на предприятии информационной системы класса ERP.

Сегодня эффективная работа предприятий, особенно производственных и торговых, невозможна без ERP (Enterprise Resource Planning). Идеальная ERP-система - интегрированная, т.е. способная автоматизировать все ключевые производственные задачи, от документооборота до движения денежных средств. Самые популярные на сегодня комплексные ERP-системы в Казахстане и СНГ - немецкая SAP и российская $1 \mathrm{C}$. Представленные ERP-системы построены по принципу единого приложения, ориентированы на организацию работы крупных предприятий, имеют значительно избыточный для малых предприятий функционал и не позволяют подбирать клиенту для закупки минимально необходимую конфигурацию. Также следует отметить, что для приобретения данных систем требуются значительные денежные инвестиции, значительно превышающие финансовые возможности большинства малых предприятий РК.

Одним из вроде бы явных способов решения данных проблем является внедрение облачной ERP системы.

По мнению экспертов Orange Business Services, например, для Российской Федерации, рост рынка облачных сервисов только в 2017 году может составить более $30 \%$. Аналогичная ситуация и для ИТ-рынка Казахстана.

С каждым годом российские и зарубежные компании все активнее развертывают ERP-системы в облаках. По данным Panorama Consulting Group в прошлом году 85\% компаний предпочли облачные ERP-системы, в то время как on-premise варианты использовали 15\%. При этом на $30 \%$ возросло число заказчиков SaaS-услуг, т.е. арендующих ERP в облаке по подписке. Причины тенденции - в объективных преимуществах облачной ERP.

Облачный ERP-хостинг - один из новых сервисов, который предлагают облачные провайдеры, чтобы избавить предприятие от капитальных затрат, переведя их в операционные.

Облако дает больше возможностей для гибкого масштабирования ERP-системы, в том числе «на лету», мобильность и безопасность. Не менее важна и экономия: для развертывания ERP в облаке не требуется 
закупать серверное оборудование, лицензии, заниматься обслуживанием инфраструктуры и расширять IT-штат. Кроме того, облачную ERPплатформу можно предварительно протестировать.

B результате компании, выбирающие ERP в облаке, повышают эффективность бизнеса, перспективы дальнейшего роста компании, сокращают оборотный капитал, а также штат сотрудников, плюс повышают уровень обслуживания клиентов.

При этом анализ работы компаний, перешедших на облачные технологии показал следующее:

- размещение ИТ-инфраструктуры в облаке позволяет удешевить совокупную стоимость владения ИТ на $30 \%-70 \%$;

- капитальные затраты при закупке оборудования на 70\% меньше;

- повышение ресурсов использования и обслуживания оборудования до $70 \%$ ежемесячно;

- экономия ресурсов центров обработки данных (ЦОД) (электричество, охлаждение, площади) до 50\% ежемесячно;

- сокращение затрат на резервирование оборудования на 50- 70\% при аналогичном уровне доступности ежемесячно;

- сокращение затрат на лицензирование на $30 \%$ ежемесячно;

- сокращение времени развертывания новых сервисов до 90\%.

То есть облачные технологии позволяют расширять возможности бизнеса, оптимизировать ИТ-инфраструктуру и при этом экономить. Но кроме экономических выгод, "облака" дают и качественные преимущества:

- доступность - вы получаете доступ к ресурсам из любой точки, где есть Интернет;

- отказоустойчивая работа компании (при условии наличия надежного провайдера Интернет-услуг);

- повышение безопасности за счет консолидации вычислительных ресурсов;

- повышение качества предоставляемых ИТ-услуг при меньшем количестве задействованных высококвалифицированных специалистов;

- десятикратное сокращение затрат времени на внедрение и оперативное перераспределение ресурсов.

Целевая аудитория облачной ERP-системы. Целевой аудиторией облачной ERP-системы являются предприятия малого бизнеса Республики Казахстан.

Первой особенностью целевой аудитории системы, в отличие от предприятий среднего и крупного бизнеса, является то, что подавляющая часть предприятий либо состоит из одного человека (индивидуальные предприниматели), либо это предприятия с численностью сотрудников 
менее 10 человек, которые не могут себе позволить услуги и бухгалтера и ИТ специалистов. Как правило, при возникновении потребности в таких услугах они прибегают к услугам аутсорсинговых компаний.

Маркетинговые исследования по востребованности системы проводились на территории Костанайской области. Исследования проводились в виде устного опроса предприятий малого бизнеса на предмет перехода на предлагаемое SaaS решение. Опрос проводился среди индивидуальных предпринимателей, а также товариществ с ограниченной ответственностью, применяющих налоговый режим, как на основе упрощенной декларации, так и на основе патента. Всего опрошено 290 предприятий. Результаты показывают, что 80\% (231 предприятие) опрошенных фирм проявили заинтересованность в создании проекта и перехода с имеющихся решений (в большинстве своем с решений фирмы 1С) на предлагаемое решение.

Вывод. Основными сдерживающими факторами для развития облачной ERP-модели в Казахстане являются сомнения компаний в надежности хранения финансовой и налоговой отчетности на серверах за пределами организации. Для преодоления этих страхов необходимо ответственно подходить к выбору облачного провайдера, рассматривать только тех поставщиков, которые имеют богатый опыт в предоставлении услуг виртуальной инфраструктуры IaaS, будут отвечать за надежность хранения данных ERP-сервисов. Сейчас в России и Казахстане получают распространение такие облачные услуги, как «Хостинг SAP» и «Хостинг 1C ERP».

\section{Список литературы:}

1. Облачная модель ERP для бизнеса - URL: http://profit.kz/.

2. Дэниел O'Лири. ERP системы. Современное планирование и управление ресурсами предприятия. Москва, Вершина, 2004.

3. ЕRP-системы для субъектов малого предпринимательства / Н.Б. Демироглу // ИНФОРМАЦИОННО-КОМПЬЮТЕРНЫЕ ТЕХНОЛОГИИ № 1(23) 2019 В ЭКОНОМИКЕ, ОБРАЗОВАНИИ И СОЦИАЛЬНОЙ СФЕРЕ. № 1(23) 2019. C. $28-33$.

4. Анализ перспектив развития облачной ERP-системы для малого бизнеса Казахстана / В.Р. Зарубина, М.Ю. Зарубин // Экономика и политика №2 (12) 2018. - C. $17-20$. 


\title{
RESEARCH OF BIO-PACKAGES AND CHARACTERISTICS OF PACKAGING MATERIALS
}

\author{
Kuanyshbekov Nurzhan \\ master's degree, \\ Kazakh National Agrarian Research University \\ Kazakhstan, Almaty \\ Askarbekov Erik Birlikovish \\ PhD, Kazakh National Agrarian Research University, \\ Kazakhstan, Almaty
}

\section{ИССЛЕДОВАНИЕ БИОУПАКОВОК И ХАРАКТЕРИСТИКА УПАКОВОЧНЫХ МАТЕРИАЛОВ}

\author{
Куанышбеков Нуржан \\ магистрант, \\ Қазақ ұлттық аграрлық зерттеу университеті \\ Қазақсстан, Алматы қ. \\ Аскарбеков Эрик Бирликович \\ $P h D$ \\ Казахский национальный аграрный \\ исследовательский университет, \\ Қазақстан, Алматы к.
}

В настоящее время одним из актуальных направлений становится производство экологически чистой биоразлагаемой упаковки. Биоразлагаемые материалы (биодеградируемые материалы, биопластики или биополимеры) - это класс полимеров, в состав которых входят вещества, образующиеся в результате жизнедеятельности растений или животных (целлюлоза, белок, крахмал, нуклеиновая кислота, природная смола и т. д.), а также в процессе биосинтеза в клетках живых организмов, которые могут разрушаться в естественных условиях под воздействием таких природных факторов, как свет, температура, влага, а также при участии живых микроорганизмов (бактерий, дрожжей, грибов и т.д.) на нейтральные для окружающей среды вещества. В течение короткого промежутка времени (до 6 месяцев) после помещения биоразлагаемой 
упаковки в компостные условия, она естественным образом «поедается» микроорганизмами, не нанося вреда окружающей среде. В результате разложения такой упаковки остается лишь гумус (перегной), вода и углекислый газ. Такой процесс называется «биодеградация». Таким образом, совершается естественный круговорот веществ, созданный эволюцией и способный поддерживать экологическое равновесие в природе.

Наиболее популярной сегодня становится полимерная упаковка. Отличие стеклянной и пластиковой упаковки заключается в том, что пластик гораздо легче и позволяет экономить огромные средства на транспортировке. К тому же, хранить жидкости в пластиковой бутылке намного безопаснее и удобнее. При падении упаковка из пластмассы может лишь незначительно деформироваться, но при этом полностью сохранит упакованный продукт от повреждения. Подобного нельзя сказать о стекле, осколки которого могут оказаться в продукте, что крайне опасно.

Большой популярностью пользуется стрейч-пленка, она различается по плотности, толщине, фактуре и назначению. Эластичная пленка стала широко применяться благодаря своей легкости, компактности и непревзойденным упаковочным характеристикам. Пленка предохраняет продукт от высыхания, влаги и микроорганизмов. Большим преимуществом для потребителей является то, что после вскрытия пленки, можно повторно завернуть товар в нее.

Полимеры - это не только упаковка товаров и пакеты в супермаркетах. Они буквально повсюду: корпус телефона, автомобильная шина, шариковая ручка, одноразовая посуда и т.д. Это крайне необходимый материал. Даже человеческий организм содержит полимеры в качестве естественных компонентов.

Синтетические полимеры, такие как полиэтилен, необходимо утилизировать, т.к. под действием света и кислорода эти материалы разлагаются сотни лет. Утилизация синтетических полимеров является глобальной проблемой.

Чрезвычайно обширное применение функциональных полимерных материалов, таких как пластмассы, резины, волокна, краски, суперабсорбенты, вывело науку о полимерах на передовую ступень и позволило сделать немалые успехи в современной промышленности. Объем производства полимеров составляет 580млн. т. в год, сюда входят пластики, каучуки, резины, волокна, пленки, композиционные и наполненные полимеры.

Но сохранение экологии выходит сегодня на передний план. Раньше производители стремились создать полимерную упаковку, устойчивую к факторам среды. Сегодня усилия направлены на получение полимеров, 
которые сохраняют упаковочные характеристики в течение периода потребления и хранения, а затем безопасно разлагаются под действием физико-химических и биологических факторов и легко включаются в круговорот веществ в природе.

Запасы нефти и газа, как основных источников сырья для полимеров, постепенно истощаются. Для нефти установлены совсем небольшие сроки - от 20 до 40 лет. Но еще раньше их дефицит будет расти, а цены повышаться.

Возникает вопрос: есть ли другие способы получения полимеров, подобных синтетическим, но получаемых из других видов сырья? Конечно, ими являются микробные полимеры, получаемые с помощью биотехнологий. Во всем мире уже давно осуществляют научно-технические программы, направленные на использование альтернативных источников сырья для производства различных продуктов, в том числе и полимерных материалов.

Применение биодеградируемой упаковки является ключевым решением проблемы утилизации отходов и защиты окружающей среды. Ведущие институты мира и крупнейшие производители уже взяли разработку и применение биополимеров на вооружение. В Казахстане таких производителей пока нет, в то время как проблема утилизации синтетических полимеров требует серьезного вмешательства.

Технические причины заключаются в том, что пленка обладает оптимальным соотношением внешний вид - вес, т.к. при своей легкости и эстетичном виде, она осуществляет герметизацию продукта, защиту его от влаги, химических смесей, газов.

Немаловажной является экономическая причина: пленка производится в массовом порядке, обладает низкой стоимостью. Также использование пленки открывает широкие возможности в плане дизайна, на нее можно наносить всевозможные логотипы и надписи.

Упаковка занимает 38 \% всей пластиковой продукции, а $25 \%$ производимого пластика представляют пленки. В Европе 70 \% пленок производят из полиэтилена. Средняя цена полиэтиленовой пленки в мире составляет 1,9 долл. за килограмм.

Основная идея использования биоразлагаемых пластиков - это повторение природных циклов развития. В природе 60 млрд. тонн сырья получается путем фотосинтеза, и большая часть этого органического материала разлагается микроорганизмами до первоначальных компонентов, а именно - углекислого газа и воды. Такая же модель, представленная на рисунке 1., является образцом для биоразлагаемых полимеров: когда пленки и пластики отслужат свое, их можно превратить в компост. 


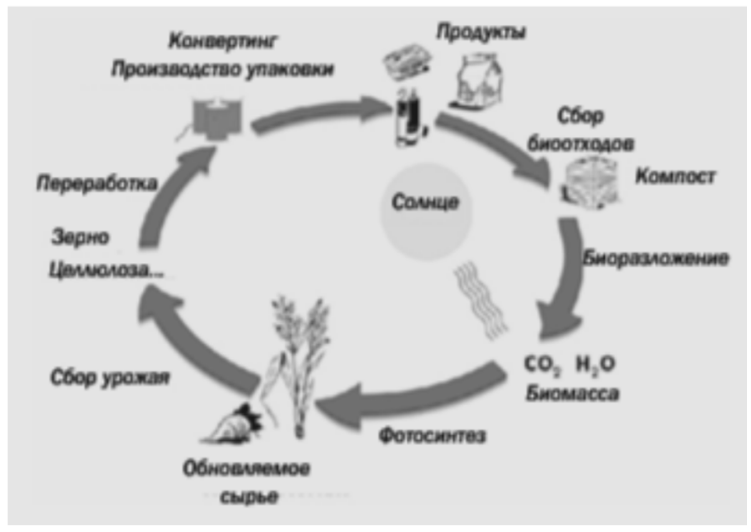

\section{Рисунок 1. Цикл производства, использования и утилизации биополимеров}

Несмотря на то, что биополимеры по своей структуре близки к традиционным синтетическим - полиэтилену, полипропилену и полиэстеру, биоразлагаемые пленки обладают собственной химической структурой, а также новыми техническими возможностями и характеристиками:

- некоторые биополимеры обладают лучшей пропускной способностью в воде, что полезно в некоторых видах обработки;

- пленки с содержанием полимолочной кислоты обладают барьерными свойствами, позволяющими использовать ее для упаковки хлебобулочных изделий и дольше сохранять их свежими;

- пленки из пшеничных смесей обеспечивают нужный уровень влажности при хранении фруктов и овощей.

Технология производства пленок из биополимеров аналогична технологии производства синтетических пленок. Здесь также применяют такие методы как ламинирование, инжектирование и экструзия. Конечный продукт снабжают печатью или этикеткой, главное, чтобы способность полимеров к разложению была сохранена.

Несмотря на то, что стоимость биодеградируемой продукции остается достаточно большой, эффективность использования этих пластиков повысилась, по сравнению с обычными. Ведь экономическая стоимость состоит не только из цены продукта, но и затрат на его использование и утилизацию. Широта применения и преимущества биоразлагаемых пластиков представлены в таблице 1 .

В связи с этим биоразлагаемые материалы сегодня активно завоевывают потребительские рынки. Возобновляемые ресурсы, которые необходимы для их производства, несомненно, более выгодны. 
Таблица 1.

Обзор областей применения биоразлагаемых пластиков

\begin{tabular}{|c|c|c|}
\hline Сегмент & Примеры & Аргументация \\
\hline Упаковка & $\begin{array}{l}\text { Фольга, плоские материалы, } \\
\text { пленка, бугылки, сети, } \\
\text { блистеры, пакеты }\end{array}$ & $\begin{array}{l}\text { Пищевая упаковка подлежит } \\
\text { разложению, а не } \\
\text { переработке, которая не } \\
\text { всегда возможна. }\end{array}$ \\
\hline $\begin{array}{l}\text { Фастфуд и } \\
\text { ресторанное питание }\end{array}$ & $\begin{array}{l}\text { Посуда, мерные стаканчики, } \\
\text { соломки, столовые приборы }\end{array}$ & $\begin{array}{l}\text { Одноразовая посуда } \\
\text { предпочтительнее и } \\
\text { дешевле, одноразовая } \\
\text { посуда не оказывает } \\
\text { вредного воздействия при } \\
\text { контакте с продуктами }\end{array}$ \\
\hline $\begin{array}{l}\text { Волоконное } \\
\text { производство, } \\
\text { текстиль }\end{array}$ & $\begin{array}{l}\text { Волокно, текстиль, } \\
\text { техническая одежда }\end{array}$ & \begin{tabular}{|l} 
Дышащие, приятные на \\
ощупь, блестящие ткани
\end{tabular} \\
\hline Игрушки & $\begin{array}{l}\text { Кубики, мячики, } \\
\text { конструкторы }\end{array}$ & $\begin{array}{l}\text { Образовательные цели } \\
\text { использования, } \\
\text { экологическая безопасность }\end{array}$ \\
\hline Удобства & $\begin{array}{l}\text { Мешки для мусора, } \\
\text { средства личной гигиены }\end{array}$ & $\begin{array}{l}\text { Натуральные материалы, } \\
\text { легко подлежат разложению }\end{array}$ \\
\hline Садоводство & \begin{tabular}{|l|} 
Цветочные горшки, \\
пакетики для семян,т \\
укрывающие пленочные \\
покрытия
\end{tabular} & $\begin{array}{l}\text { Экономичные материалы, } \\
\text { переработка не требует } \\
\text { больших затрат }\end{array}$ \\
\hline Сельское хозяйство & Разнообразные пленки & $\begin{array}{l}\text { Те же преимущества, что и } \\
\text { для садоводства }\end{array}$ \\
\hline Медицина & $\begin{array}{l}\text { Имплантанты, средства } \\
\text { гигиены полости рта, } \\
\text { операционные материалы, } \\
\text { перчатки }\end{array}$ & $\begin{array}{l}\text { Гигиеническая надежность, } \\
\text { короткий срок } \\
\text { использования }\end{array}$ \\
\hline Другое & \begin{tabular}{|l|} 
Функциональная \\
поддержка, \\
технологические установки, \\
канцелярские товары
\end{tabular} & $\begin{array}{l}\text { Широкий спектр обработок, } \\
\text { низкие экономические } \\
\text { затраты на утилизацию, } \\
\text { возможность } \\
\text { компостирования }\end{array}$ \\
\hline
\end{tabular}

\section{Список литературы:}

1. Баймурзаев А.С. Биоразлагаемые высоконаполненные композиции на основе полиэтилена / А.С. Баймурзаев, Л.Н.Студеникина, Н.А. Балакирева // Экология и промышленность России. - 2012. - № 3. - С. 9-11.

2. Балов А. Мировой рынок биополимеров / А. Балов, О. Ашпина // The Chemical Journal. - 2012. - №3. - C. 48-53. 
3. Легонькова О.А. Биоутилизация крупнотоннажного упаковочного материала в пищевой промышленности / О.А. Легонькова, М.С. Федотова, О.В. Селицкая / Пищевая промышленность. - 2011. - №5. - С. 74-77.

4. Легонькова О.А. Материаловедческие основы упаковки продуктов животного происхождения / О.А. Легонькова, М.С. Федотова // Пищевая промышленность. - 2011. - № 1. - С. 8-14.

5. Легонькова О.А. Упаковочные материалы из биоразлагаемых материалов на основе полилактида и крахмала / О.А. Легонькова // Пищевая промышленность. - 2009. - №6. - С. 12-13. 


\section{SECTION 4.}

\section{PHARMACEUTICAL SCIENCES}

\section{USING THE EDUCATIONAL INSTITUTION SITE FOR MIXED EDUCATION IN HIGHER PHARMACEUTICAL EDUCATION}

Tatiana Litvinova Associate Professor, Candidate of Pharmaceutical Sciences, Sechenov First Moscow State Medical University, Russia, Moscow

Evgeniia Budenkova

Graduate student, Sechenov First Moscow State Medical University, Russia, Moscow

Liudmila Babaskina

Professor, Doctor of Pharmacy, Sechenov First Moscow State Medical University,

Russia, Moscow

Dmitrii Babaskin

Associate Professor, Doctor of Medical Sciences, Sechenov First Moscow State Medical University,

Russia, Moscow

Irina Galuzina Assistant,

Sechenov First Moscow State Medical University, Russia, Moscow

At present, various information systems for higher education have been developed and are functioning in the world information and educational space. For the implementation of modern tasks of the development of a higher educational institution, portal technologies are best suited [1,2]. They ensure the development of a single information space, allow organizing the use of 
information resources, and managing information flows of a higher educational institution.

At Sechenov First Moscow State Medical University, a Unified educational portal (UEP) was created based on the Learning Management System with educational content Moodle Mobile. The UEP resource has a wide range of functionalities, including the placement and storage of information and educational modules of any format (educational and methodological complexes of disciplines and specialties, multimedia and interactive manuals, educational films, etc.). The built-in system for managing distance learning and educational content automatically collects and analyzes statistical information accumulated in the process of using the portal. For each user of the portal, a report is generated containing data on the date, time, and duration of work with a specific resource, results, and assessments of work with meaningful elements, for example, with practical assignments or tests. UEP provides:

- creation and development of the environment of the network community of Sechenov University through the built-in forum, the ability to blog (network logs or event diaries), chat and e-mail;

- forming a newsgroup and conducting a survey of users, which ensures prompt informing of users about changes and events in the subject area or area of interest of the user both in the content of the portal and in the environment.

Blended learning in higher pharmaceutical and medical education has become the most relevant recently, as it allows you to make the learning process more mobile, accessible, and adaptable to environmental conditions, which is especially important during a pandemic, natural disaster, or man-made disaster [3-5].

The study purpose is to study the possibility of using a portal of a higher educational institution for organizing blended learning (model of an inverted classroom) in the discipline 'Pharmaceutical Marketing' using the example of the Unified educational portal Sechenov First Moscow State Medical University.

Materials and methods. UEP Sechenov First Moscow State Medical University (https://www.sechenov.ru/pressroom/news/edinyy-obrazovatelnyyportal-eop/). The developed content for UEP is an electronic educational and methodological complex for the discipline 'Pharmaceutical Marketing', including a work program, video lectures, electronic teaching aids for students and teachers, explication and explanatory videos (for each topic, 2030 minutes), an electronic work a notebook, a fund of assessment tools (test tasks and professional situational tasks), requirements for the procedure for conducting various types of test control at UEP and testing practical skills, a list and procedure for using teaching aids at UEP. The modified electronic educational-methodical complex was uploaded to the UEP in the research 
module of the discipline 'Pharmaceutical Marketing' before the start of classes.

The study involved 4th-year students (104 people from 8 educational groups), studying in the specialty 'Pharmacy' (specialty). 52 students (4 study groups) were engaged in an inverted classroom (FC) model. The remaining 52 participants (4 training groups) were trained according to the traditional model (CC). The students of the FC group were introduced to the methodology and technology of the inverted classroom model. To assess the effectiveness of training, test control (final centralized testing at UEP, on a 100-point scale) and a test of practical skills on professional situational tasks (on a 10-point scale) were used.

Statistical processing of the results was carried out using the SPSS. Statistics. v17. Multilingual-EQUiNOX program (SPSS Inc). The results of the study were expressed as means \pm standard deviation $(\mathrm{M} \pm \mathrm{SD})$.

Results and discussion. The UEP was supposed to be used at the first stage of training in self-preparation for practical exercises (extracurricular work). Students had to study the materials on the topic of the current lesson included in the electronic educational and methodological complex, and complete their homework on solving cases, filling out flowcharts, developing a presentation, writing an essay, essay, and more. The use of explication and explanatory videos made it possible to introduce the student to the problems of the current topic in a short time, to consider the methodology for completing homework, and to show the relationship between homework and solving situational problems in a practical lesson. At this stage, it was supposed to conduct an online discussion through the built-in forum at the UEP of current topical issues on the topic, methodological and didactic recommendations. Homework results and assessments were recorded in the network log on the UEP.

At the second stage of training in practical classes (classroom work), students solved situational tasks according to the indicative foundations of action and solution standards presented at the UEP in the section of teaching aids. Homework, as a rule, was a fragment of one or more situational tasks performed by them. In practical classes, the students discussed the key points in solving situational problems, presented their presentations, listened to reports on completed abstracts and essays. As a result, an individual or collective opinion on the current occupation was developed. The results and assessments of the implementation of situational tasks were recorded in the network log on the UEP.

An analysis of the effectiveness of training in the discipline 'Pharmaceutical Marketing' showed the superiority of the inverted classroom model using UEP over the traditional training model, both in terms of the 
formation of skills in solving situational problems, and according to the results of the final centralized testing $(p<0.05)$ (figure).

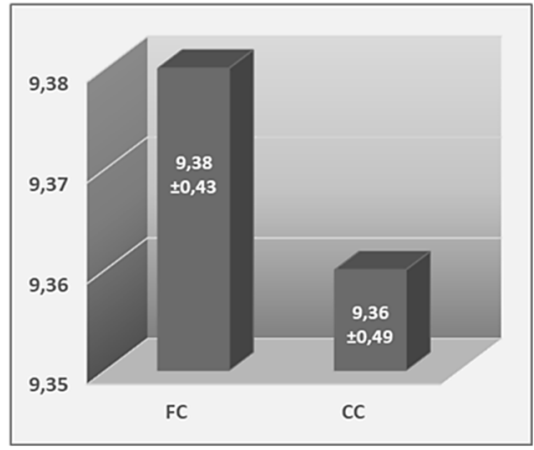

A

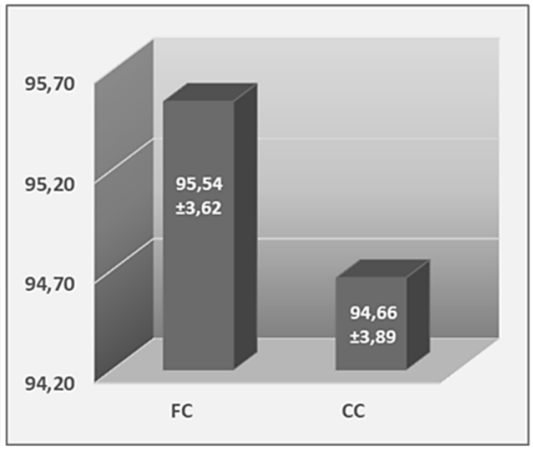

$\mathrm{B}$

Figure. Results of practical skills test (A) and final centralized testing (B) using the inverted classroom model $(F C)$ and the traditional learning model (CC)

The abscissa is the training model, the ordinate is the estimate, score, $\mathrm{M} \pm \mathrm{CD}$

\section{Conclusion}

1. As a result of the study, it was established that the portal of a higher educational institution (UEP Sechenov First Moscow State Medical University) can be used to organize blended learning (inverted classroom model) in the discipline 'Pharmaceutical Marketing'.

2. Students studying according to the inverted classroom model showed significantly higher results both in solving professional situational problems in practical skills and the final centralized testing at UEP.

\section{References:}

1. Kim KJ, Kim G. Development of e-learning in medical education: 10 years' experience of Korean medical schools. Korean J Med Educ. 2019 Sep;31(3):205214. DOI: 10.3946/kjme.2019.131. Epub 2019 Aug 26.

2. Willis MH, Newell AD, Fotos J, Germaine P, Gilpin JW, Lewis K, Stein MW, Straus C, Sepulveda KA. Multisite Implementation of Radiology-TEACHES (Technology-Enhanced Appropriateness Criteria Home for Education Simulation). J Am Coll Radiol. 2020 May;17(5):652-661. DOI: 10.1016/j.jacr.2019.12.012. Epub 2020 Jan 10. 
3. Decloedt A, Franco D, Martlé V, Baert A, Verwulgen A, Valcke M. Development of Surgical Competence in Veterinary Students Using a Flipped Classroom Approach. J Vet Med Educ. 2020 Feb 28:e20190060. DOI: 10.3138/jvme.2019-0060.

4. French H, Arias-Shah A, Gisondo C, Gray MM. Perspectives: The Flipped Classroom in Graduate Medical Education. Neoreviews. 2020 Mar;21(3):e150e156. DOI: 10.1542/neo.21-3-e150.

5. Ge L, Chen Y, Yan C, Chen Z, Liu J. Effectiveness of flipped classroom vs traditional lectures in radiology education: A meta-analysis. Medicine (Baltimore). 2020 Oct 2;99(40):e22430. DOI: 10.1097/MD.0000000000022430. 


\title{
SECTION 5.
}

\section{PHILOLOGY}

DOI: 10.32743/NetherlandsConf.2021.4.6.261450

\section{SYNTACTICAL STYLISTIC WAYS OF CREATING IRONY IN ENGLISH LANGUAGE}

\author{
Angelina Bakhanovich \\ graduate student, Minsk State Linguistic University, \\ Belarus, Minsk
}

The combination of elements of expressive syntax with graphic emphasis, context and appropriate intonation becomes one of the ways of creating a comic effect. Among the multilevel markers of irony, syntactic means are of fundamental importance, since they allow not only to transmit basic information, but also to introduce additional data, thus carrying out an aesthetic suggestion in relation to the recipient of a literary text.

It is important to emphasize that complex sentences are one of the leading forms of expressing comparative semantics at the syntactic level, due to the presence of a two-term structure, as well as the presence of conjunctions and union words used in order to express these relations.

The most dependent syntactic means of irony explication are introductory constructions, subordinate to the lexical content of the utterance. In view of the functional peculiarity of introductory constructions, which consists in the expression of subjective modality, they can be qualified as an inalienable marker of irony. The use of introductory constructions as a way of creating irony allows the speaker, in this case Stephen Fry, in his autobiography, to assess the situation with the help of the introductory structure you might say. This structure indicates the presence of the opposite meaning and that the speaker is not the culprit of the current the situation: I have brought, you might say, gorgeous palaces, noble properties and elegant honest establishments into disrepute [1, p. 71].

Author's ironic comment or remark in brackets as an element of an expressive syntax plays an important role in the structure of a literary text. Despite the graphic isolation from the main context, from an informative point of view, they turn out to be closely related to the content of the 
utterance, expressing the speaker's subjective attitude to the information presented, adding an emotional coloring and a shade of comic effect.

The humorous effect is achieved due to the contradiction between the neutral (and sometimes sublime) tone of the narrative and the author's sarcastic remark in brackets. The author's comment is necessary in order to emphasize and contrast the word children and their almost forty years of age. Bridget in this example criticizes what she considers faulty and mediocre. She ridicules her parents' attempts to treat adult children as infantile adolescents: Mum, with dazzling bravado, has planned schmaltzy family Christmas with her and Dad pretending the whole of last year never happened 'for the sake of the children' (i.e. me and Jamie, who is thirty-seven) [2, p. 149].

A rhetorical question for the creation of irony is characteristic of all the studied works. A rhetorical question is an affirmative sentence, which is only framed in a questioning form, the purpose of which is to draw attention to the statement, giving it richness and expressiveness.

In the example below, the antiphrasis is implemented with the help of the rhetorical question: straw donkey ('Isn't it super?'). A detailed study of the context allows to establish the presence of irony. It is about Bridget's mother, who is described as an eccentric and fickle lady. And the fact that a woman of advanced years, running away with her lover, takes a straw donkey with her on the road cannot but cause hidden mockery from Bridget: Dad had finished putting all her suitcases, hats, straw donkey ('Isn't it super?') and castanets in the trunk of the Sierra and had started the engine [2, p. 142].

The defining of a statement as ironic requires the analysis of both a narrow and a wide context, which is proved by the following example of the use of associative irony, which demands the reader to know the situation. Clumsy Ted Wallis, while in the bathroom, pinched his finger with the zipper of his trousers, slipped, doused himself with water and almost caused a flood in the house. The whole situation is quite comical. With the help of rhetorical questions, Ted expresses his emotional attitude to the situation. Naming places that are clearly remote from home, he emphasizes the absurdity of the question asked and the fact that the hostess is already aware of the mess in her bathroom. Next is a part of the dialogue between Ted and the hostess:

- 'All this took place in a bathroom?'

- 'Yes! In a bathroom. What did you expect, a bakery? A hair-dressing salon? [3, p. 241].

Antithesis is a figure of speech, consisting in a sharp opposition of compared concepts, thoughts, images, built on antonymy and syntactic parallelism, serving to create contrast, enhance the expressiveness of speech. In the works under study, the antithesis repeatedly generates an ironic context.

In the example below, the antithesis arises through the use of mutually 
contradictory concepts: to cheer up and criticize. Criticism always has a negative effect on mood, but not in the following case: Eventually I managed to cheer Mum up by allowing her to go through my wardrobe and criticize all my clothes [2, p. 41].

We should pay attention to another example of antithesis in Stephen Fry's novel. The author uses a productive way of creating an ironic statement - the use of contrasting compositional elements: a large nature and small bank balance. It should be noted that this cognitive alogism is a characteristic feature of dialogical speech, which intonationally intensifies irony. For the main character, as a cynical person, it is typical to exalt material wealth over spiritual:

- Your Uncle Michael, on the other hand, has a large nature...

- But small bank balance [3, p. 186].

Repetitions, which are relevant for a separate piece of text, are characteristic in the group of syntactic means. Repetitions focus the reader's attention on the author's most important thoughts. Highlighting different shades of the meaning of the same subject, re-nomination allows the reader to see and evaluate the depicted in a new way. Repetition in a literary text contributes to the appearance of additional meanings in a linguistic unit, increases its content-richness and expands its functionality.

In the example from the novel «Bridget Jones's Diary», the irony is based on a syntactic anaphora: the same syntactic construction (Eighteen years of) was used four times, intensified by a quantitative hyperbole (Millions of cheesecakes ..., tens of millions) and ends with a rhetorical question. Bridget is trying to answer the question, "if for 18 years she has not met a man, then why this endless struggle with kilograms?" The cycle of self-flagellation ends with a figurative comparison (I feel like a scientist who discovers that his life's work has been a total mistake): Eighteen years - wasted. Eighteen years of calorie-and fat-unit-based arithmetic. Eighteen years of buying long shirts and sweaters and leaving the room backwards in intimate situations to hide my bottom. Millions of cheesecakes and tiramisus, tens of millions of Emmenthal slices left uneaten. Eighteen years of struggle, sacrifice and endeavor-for what? Eighteen years and the result is 'tired and flat.' I feel like a scientist who discovers that his life's work has been a total mistake [2, p. 58].

Syntactic parallelism, characterized by a similar structure of several sentences or separate segments of speech, within one sentence. Lexical filling in this case will play a secondary role. The expressiveness of such a statement is enhanced with each repetitive parallel construction, in this case, with homogeneous predicates. The author emphasizes the hero's excessive concern with his appearance, especially before entering the locker room and changing clothes, which creates alogism, the purpose of which is to create a 
comic effect: Adrian checked the orchid at the buttonhole, inspected the spats at his feet, gave lavender gloves a twitch, smoothed down his waistcoat, swallowed twice and pushed wide the changing-room door [4, p. 7].

Climax (ascending gradation), or the gradual, deliberate intensification of comic effect, is also one of the means of creating irony. This technique represents a syntactic construction with a specific set of words, arranged in a specific order. The function consists in placing the correct emphasis in the statement and creating the effect of increasing of the produced impression.

Bridget Jones enumerates the types of men you shouldn't fall in love with. She considered alcoholics on this list the least dangerous, while perverts occupy the last line of the, that means that they are the least desirable candidates for her hand. Gradation consists in the sequential forcing of images of artistic speech: I WILL NOT Fall for any of following: alcoholics, workaholics, commitment phobics, people with girlfriends or wives, misogynists, megalomaniacs, chauvinists, emotional fuckwits or freeloaders, perverts [2, p. 14].

Ted Wallis, like Bridget, described the vices of actors and TV presenters, arranging expressions related to their disadvantages in order of the increasing emotional significance of the members of the series (emotional build-up): 'What a perfect marriage they had, and what ideal parents they were. A golden couple.' I could there be describing actors, TV show presenters or producers with total accuracy, leaving out only their serial polygamies, chronic domestic abuse, violent orgiastic fetishes and breathtaking assaults on the bottle, the powders and the pills [3, p. 145].

Let's pay attention to examples of chaotic enumeration. In the novel "Bridget Jones's diary", based on the following examples, the reader reconstructs the image of Bridget's mother as an unbalanced, illogical and completely unpredictable woman. She can end up in a hairdressing salon just as easily as in Portugal:

- Where's your mother now?'

- 'I don't know. Portugal? Rio de Janeiro? Having her hair done?' [2, p. 1391.

Asyndeton is a stylistic technique in which conjunctions, which connect words and sentences in a phrase, are omitted. As a result, speech acquires rhythm, conciseness, compactness, the impression of a swiftness and a quick change of the picture. Stephen Fry shows this by the example of a teenage love letters, with a significant number of repetitions, lack of conjunctions, thus creating an ironic, naïve image: I love your big dark eyes. I love your mess of hair, your very red lips. They are very red in fact; I bet you did not know that. Very few people have lips really red in the way poets write about red. Yours are the reddest red [5, p. 6]. 
Parcelling is the arrangement of intonation in a narrative by dividing a certain text in semantically relevant segments. In the presence of a certain context, it also contributes to giving ironical coloring to the statement. Parcelling sets the pace and rhythm of speech, helps to highlight exactly what the hero, the writer pays attention to.

In the novel "The Stars' Tennis Balls", parceling emphasizes the hero's ironic attitude to the behavior of the other characters. Highlighting of the adverb solemnly in a punctuationally and intonationally independent segment sharpens the reader's attention on what is happening, particularly on the conversation between the father and his rebellious daughter. The discrepancy between the positive semantics of the accent adverb and the situation is emphasized: Pete, of course, after going as red as Lenin, swallowed his rage and his baffled pride and began to talk to me. Solemnly [5, p. 6].

The peculiarity of the use of syntactic and stylistic devices for creating irony is the fact that they do not generate an ironic statement by themselves, but only convey meaning with increased intensity, the result of which is emotional or logical strengthening, giving the utterance more imagery. Introductory constructions and author's comments in brackets in the studied texts are most widespread. Irony in this case is created due to the contradiction between the expressed opinion and the author's sharp comment, which can be presented in the form of detailing the information of the main sentence, unfolding an unexpected assessment of the narrator. The rhetorical question is also widely used by writers, since contextual conditioning, as well as a combination with one of the types of irony (self-irony or associative irony) give a rhetorical question a touch of irony.

\section{References:}

1. Fry, S. More fool me / S. Fry. - London : Penguin Books, 2015. - 388 p.

2. Fielding, H. Bridget Jones's diary / H. Fielding. - London : Picador, 1996. -307 p.

3. Fry, S. The Hippopotamus / S. Fry. - London : Cornerstone, 2017. - 416 p.

4. Fry, S. The liar/S. Fry. - London : Arrow Books, 2011. -388 p.

5. Fry, S. The stars' tennis balls / S. Fry. - London : Arrow Books, 2011. -436 p. 


\title{
IDENTIFICATION OF THE ELDER AGE IN RUSSIAN AND CHINESE LANGUAGES
}

\author{
Yan Zhuo \\ Postgraduate student, \\ Moscow State University n.a. M.V. Lomonosov, \\ Russia, Moscow
}

\section{ОБОЗНАЧЕНИЕ СТАРШЕГО ВОЗРАСТА В РУССКОМ И КИТАЙСКОМ ЯЗЫКАХ}

\author{
Янь Чжно \\ аспирант, \\ Московский государственный университет \\ имени М.В. Ломоносова, \\ РФ, г. Москва
}

В первую очередь, в статье проводится полный анализ проблемы обозначения лиц старшего возраста на примере русского и китайского языка. С помощью компонентного анализа и статистических методов выявлена структура фрагментов "старости" лексико-семантического поля "возраст" в русском и китайском языках, а также проведен их сравнительный анализ.

Такое понятие, как «возраст», играет важную роль в концептуализации мира, поскольку на основе представлений, знаний, оценок, связанных с возрастными периодами жизни человека, происходит осмысление различных явлений действительности. В связи с этим безусловную актуальность приобретают исследования различных аспектов указанного понятия. Однако в большинстве работ данного направления выявляется национальная специфика возрастных концептов посредством сравнения их вербализаций в разных языках (Н.В. Крючкова, Е.И. Бондаренко, Д. Кацкова, Ю.В. Матвеев, Н.А. Серебрякова), анализируется разница в объеме и границах обозначаемых понятий в разных языковых сообществах (В.Г. Гак), исследуются преимущественно частные возрастные концепты на разножанровом языковом материале (А.Т. Ашхарова) либо разные концепты в рамках одного жанра (Н.Н. Кузнецова), проводятся диахронические и региональные исследования по данной проблематике (Е.И. Зиновьева, Г.И. Любимова) Комплексный же анализ вербализации этого понятия, насколько нам известно, ранее не проводился. 
Исследованию лексической системы языка посвятили свои работы В.В. Виноградов, В.М. Солнцев, А.А. Уфимцева, Д.Н. Шмелев, Г.С. Щур, Ю.Н. Караулов, З.Д. Попова, И.А. Стернин, Ю.С. Степанов, Э.В. Кузнецова, Н.Ю. Шведова, Ю.Д. Апресян, Л.А. Новиков, С.Г. Шафиков и др. Однако вопрос о систематизации лексики остается открытым и стоит особенно остро. Лингвистика на современном этапе характеризуется интенсивным развитием структурно-семантического подхода к описанию лексического состава языка, обращением к изучению различных семантических объединений, разработкой теории семантического поля.

Семантическое поле «возраст» является относительно замкнутой, устойчивой в своем составе, редко пополняемой лексико-фразеологической парадигмой, характеризующейся развитой системой образных наименований. Особенностью поля «возраст» является асимметрия в назывании лиц по возрасту, которая заключается в преобладании номинаций для обозначения периодов детства, молодости и старости.

Все исследования статье основаны, прежде всего, на использовании методов компонентного анализа, семантического поля, контекстного и статистического методов. Компонентный анализ позволяет выявить общую для лексем сему «старший возраст», присутствующую в их значении. Метод семантического поля используется для построения фрагментов "старости" в русском и китайском языках. Контекстный подход позволяет выявить семантические особенности словосочетаний, играющих роль в художественном тексте. С помощью статистических методов выявляются наиболее часто используемые словосочетания, составляющие ядро изучаемого фрагмента лексико-семантического поля "возраст". Источником слова "старость" являются толковые словари русского и китайского языков. Из корпусов изучаемых языков были извлечены примеры словообразовательных функций.

В первую очередь в статье проводился системно-семантический анализ лексики русского языка, который обозначает «старший возраст». По итогу анализа был определен полный состав существительных, прилагательных и глаголов, обозначающих старший возраст.

1. Существительные, которые входят в состав фрагмента «старший возраст» лексико-семантического поля «возраст».

a) существительные, которые используются для обозначения людей старшего возраста: 'дядя’, 'тетя’, 'тетушка', 'тетка', 'тетенька', 'тетечка', 'тетуся', 'тетька', 'теточка', 'дяденька', 'дядечка', 'дядюшка', 'дядища', 'дядько', 'бабушка', 'дедушка', 'старуха', 'старик’, 'баба', ‘бабка', ‘старушка', ‘дед’, 'пенсионер', 'старец', 'старикан', ‘старчище', 'старче', 'старичина', 'старичишка', 'старейшина', 'отец’ являются 
существительными, характеризующие людей преклонного возраста.

б) существительные, которые используются для обозначения периода времени: 'старость', 'дряхлость', 'взрослость', 'зрелость', 'осень жизни', 'древность', 'старчество', 'вечер жизни', 'ветхость', 'престарелость'. Среди вышеперечисленных существительных необходимо отметить присутствие лексем с положительной коннотацией, например, 'зрелость', имеющей дифференциальную сему «опытность, мастерство», а также лексем с негативной коннотацией, к которым относятся 'дряхлость', имеющей семантический признак «слабость, обветшалость».

2. Прилагательные, которые входят в состав фрагмента «старший возраст» лексико-семантического поля «возраст»: 'старый', 'старший', 'старейший', 'взрослый', 'зрелый'

Среди лексем-прилагательных, имеющих сему «старший возраст», к числу наиболее часто используемых относятся 'старый'

3. Глаголы, которые входят в состав фрагмента «старший возраст» лексико-семантического поля «возраст», включают 'стареть', 'дряхлеть', 'созревать', 'увядать', 'ветшать', 'стариться', 'дряхлеть', 'изживать себя', 'отживать свой век'. Все они обозначают процесс перехода из молодого, неопытного состояния в более опытное, зрелое. Среди глаголов наиболее употребительным является глагол 'стареть'.

По итогу первой половины статьи можно сделать вывод, что ядро фрагмента «старший возраст» лексико-семантического поля «возраст» представлено лексемами 'старик', ‘дед’, ‘бабушка', 'баба', ‘тетя', 'старый'.

Вторая часть статьи посвящена анализу китайского языка. В китайском языке был также проведен структурный анализ состава фрагмента «старший возраст» лексико-семантического поля «возраст».

1. Существительные, которые обозначают людей старшего возраста: 叔叔 shushu 'дядя, 阿姨 ауі 'тетя', 爷爷 уеуе 'дедушка', 奶奶 'nainai' 'бабушка'. Также китайские лексемы, обозначающие людей старшего возраста, зачастую являются мотивированными внешними признаками, например, 黄发 huangfa 'досл. пожелтевшие волосы, знач. старик', 二毛 ermaо 'досл. вторая шерсть, знач. пожилой человек’, 斑白 banbai 'досл. наполовину седой, знач. старец', 垂白 chuibai 'досл. седовласый, знач. старик’, 戴白 daibai ‘досл. убеленный сединами, знач. старик', 白首 baishou 'досл. седая голова, знач. старик'.

2. Прилагательные фрагмента «старший возраст» лексикосемантического поля «возраст» включают в свой состав лексемы 'знач. старый, престарелый, пожилой, дряхлый, старинный', 陈 chen 'знач. старый, устарелый, выдержанный', 旧 jiu 'знач. стародавний’, 衰 shuai 
'знач. дряхлый' Прилагательное 老 аао может использовать как в качестве самостоятельного прилагательного, так и при обращении к кому-либо, образуя форму «老 lao + имя / друг / степень родства / общепринятая форма обращения». В этом случае $⿱ ⿻ 土 ㇒ 匕$ lао будет эквивалентным русскому старый, старший, почтенный, уважаемый.

3. Глаголы фрагмента «старший возраст» лексико-семантического поля «возраст» представлены немногочисленно, среди них 衰老 shuailao 'стареть, дряхлеть', 变老 bianlao 'досл. превращаться в старого, знач. стареть'. Также может просто быть использован глагол $⿱ ⿻ 土 ㇒ 匕$, например, 他 说他老了, 但觉得并不痛苦 (马国亮) Он сказал он постарел, но он не чувствовал боли (Ма Голян).

По результатам анализа второй половины статьи наиболее употребительной лексемой, которая обозначает старший возраст является $⿱ ⿻ 土 ㇒ 匕$. Данная лексема в китайском языке представляет сему «старший, старый».

Таким образом, в результате сравнения фрагментов "старости" лексико-семантического поля "возраст" было выявлено, что распространенность русского и китайского языков свидетельствует о наличии уважительных обращений. Явные отличительные черты на лексическом уровне отмечены в китайском языке, который не обозначает старость как период человеческой жизни. Отличительные черты в языковом и культурном уровнях также очевидны: в Китае старость сама по себе в основном означает опыт, уважение, поэтому, используя это слово, вы можете проявить уважительный жест. В России старость чаще ассоциируется с атрофией, старением, потерей внешней красоты, разума и памяти.

\section{Список литературы:}

1. Большой толковый словарь русского языка / Гл. ред. С.А. Кузнецов. - СПб.: «Норинт», 1998. - 1536 с.

2. Доу Чуньяо, Ковшова М.Л. Концептуализация возраста в русской и китайской фразеологии: к постановке проблемы // Лингвокультурологические исследования: Язык лингвокультурологии: теория vs. эмпирия. М.: ЛЕНАНД, 2016. С. 227-230.

3. Левицкий А.Э. Сопоставительная лингвистика в контексте профессиональной подготовки по иностранным языкам // Вестник Московской международной академии. № 1. 2018. С. 40-49.

4. Стернин И.А., Рудакова А.В. Словарные дефиниции и семантический анализ. - Воронеж: «Истоки», 2017. - 33 с.

5. Телия В.Н. Русская фразеология. Семантический, прагматический и лингвокультурологический аспекты. - М.: Школа «Языки русской культуры», 1996. - 288 с. 


\title{
SECTION 6.
}

\section{ECONOMICS}

DOI: 10.32743/NetherlandsConf.2021.3.5.255689

\section{METHODS OF STATE REGULATION OF THE ECONOMY: THE ROLE OF MONETARY RELATIONS}

Ruslan Laliev

Post-graduate student

of the North Ossetian state University named of K.L. Khetagurov, Faculty of Economics and Management,

Russia, Vladikavkaz

\section{МЕТОДЫ ГОСУДАРСТВЕННОГО РЕГУЛИРОВАНИЯ ЭКОНОМИКИ: РОЛЬ ДЕНЕЖНО КРЕДИТНЫХ ОТНОШЕНИЙ}

\author{
Лалиев Руслан Эмзарович \\ аспирант \\ Северо-Осетинского государственного \\ университета имени К.Л. Хетагурова, \\ факультет экономики и управления, \\ РФ, г. Владикавказ
}

\begin{abstract}
The strengthening of the interconnections of the economies of different countries, the strengthening of the interdependence of these economies, gives hope for stability in the world of tomorrow. It is the strengthening of such relationships that contributes to the rapid global progress, characterized by the growing volume of the money supply and the growth of financial market segments.

In connection with the recent events in the world, after the pandemic, much has been revised, but it became clear that interethnic relations need to continue to develop. In the real world, when the market suffered losses while
\end{abstract}


fighting the pandemic, it is at this time that the role of the state in the economy is a lifeline. In this regard, monetary relations and the role of the state in the economy are undergoing a transformation in the views, theories and concepts of various scientists, adapting to the influence of the world economy and the globalization of world finance. The main task in such changes is to help the real sector to adapt to the new realities. In this regard, there is a question of continuity and determining the right guidelines, global changes, new trends, it is worth preparing by studying the history, namely the works of scientists devoted to the problems of state regulation of the economy and the role of monetary relations.

\section{АННОТАЦИЯ}

Усиление взаимосвязей экономик различных стран, усиление взаимозависимости этих экономик, дает надежду на стабильность в мире завтрашнего дня. Именно усиление таких взаимоотношений способствует бурному глобальному прогрессу, характеризующемуся растущим объемом денежной массы и ростом сегментов финансового рынка.

В связи с последними событиями в мире, после пандемии, многое было пересмотрено, однако стало понятно, что межнациональные связи необходимо продолжать развивать. В реалиях, когда рынок претерпевал убытки, борясь с пандемией, именно в это время роль государства в экономике является спасательным кругом. В этой связи денежнокредитные отношения и роль государства в экономике, претерпевают трансформацию, в воззрениях, теориях и концепциях различных ученых, адаптируясь под влиянием мировой экономики и глобализации мировых финансов. Главная задачей в таких переменах является помощь реальному сектору к адаптации новым реалиям.

В этой связи встает вопрос преемственности и определения верных ориентиров, глобальные изменения, новые веяния, стоит подготовиться, изучив историю, а именно труды ученных посвященные проблематике государственного регулирования экономики и роли денежно-кредитных отношений.

Keywords: monetary relations, monetary policy, key interest rate, state regulation of the economy.

Ключевые слова: денежно-кредитные отношения, денежнокредитная политика, ключевая процентная ставка, государственное регулирование экономики. 


\section{Введение}

Начать стоит с определения денежно-кредитных отношений, однако подробного определения для данного понятия, не нашлось ни в одном проработанном научном труде. Однако можно выделить следующее, некоторые экономисты трактуют их как «общественные отношения, возникающие в сфере денежно-кредитного обращения, государственного кредита и кредита Центрального банка РФ» или «общественные отношения в сфере регулирования денежного обращения, государственного и банковского кредита» [1, C - 21]. По мнению автора, денежно-кредитные отношения куда шире, являясь важным рычагом экономического развития, участвующие в обеспечении устойчивости национальной валюты, в том числе стабильности покупательной способности. В статье рассмотрены денежно-кредитные отношения и методы государственного регулирования экономики.

Формирование иелей статьи. Изменения мировой среды, темпы с которыми меняется глобальная экономика, ставит новые задачи перед экономикой, которые должны решаться. Методы государственного участия выходят на новый уровень претерпевая изменения, как и денежнокредитные отношения, трансформируются инструменты регулирования и появляются новые, что предопределяет направление для необходимости разбора основных элементов, а именно понимания инструментов государственного регулирования и методов денежно-кредитных отношений, что и является целью настоящего исследования.

Используемые в исследовании методы, методики и технологии. В данной статье использовались критический и сравнительный анализ, системный подход к изучению информации, на основании которых были исследованы действующие теории и определения денежно-кредитных отношений.

Изложение основного материала исследования с полным обоснованием полученных научных результатов.

Финансы отображают уровень влияния на макроэкономические процессы в хозяйственной жизни различных производственных сил, а также сам уровень развития отдельными инструментами. В финансовой структуре, деньги и кредит постоянно находятся в движении, чем и способствуют возникновению отношений между участниками, между субъектом и объектом. Что представляют сами деньги и кредит, многие экономисты оценивают и трактуют по-разному. Едины, экономические школы лишь в понимании, что деньги являются одним из основных элементов рыночного хозяйства. На сегодняшний день в экономической теории принята за основу, данное определение, английского экономиста Дж. Хикса, согласно которому «деньги определяются их функциями» [2]. 
Это значит, что деньгами признается все то, что выполняет денежные функции. За этой тавтологией скрывается констатация того факта, что в роли денег могут выступать самые различные предметы и даже нематериальные объекты. Если с понимание денег в экономике идут споры, то с кредитом более понятно. Как экономическая категория, кредит связан с движением стоимости на условиях срочности, возвратности и платности, через что выражает определенный вид общественных отношений. Структура кредита, это отношения кредитора и заемщика, которые участвуют в сделке, одно лицо (кредитор) предоставляет некий предмет, либо услугу, имеющую стоимость, другому лицу (заемщику), в обмен на обещание заплатить в будущем. Несмотря на неоднозначность определения денежно-кредитных отношений как термина, его значение в экономике играет важную роль. Так они являются важным рычагом государственного регулирования экономики на пути к экономическому развитию. Удалось выделить основные проблемы, были предложены пути решения. Изучены формы и методы государственного регулирования экономики.

Центральный банк Российской Федерации - являясь основным регулятор денежных и кредитных потоков в государстве, способен оказывать влияние на курс валюты, стабильность банковской системы, ее ликвидность и в целом на устойчивость экономики страны. Проводимые мероприятий Банка России и Правительства РФ в области регулирования денежного обращения и кредита называется денежно-кредитной политикой, которая подразделяется на политику «дешевых» или «дорогих» денег, в зависимости от экономической ситуации в стране. Для увеличения совокупных расходов, инвестиций, производства и занятости путем удешевления кредитных денег, используют политику «дешевых» денег. К данным мерам прибегают в условиях высокого уровня безработицы, общего экономического спада, когда необходимо сделать кредитные деньги более доступными. Для снижения темпов инфляции осуществляется политика «дорогих» денег, с помощью сокращения совокупных расходов и ограничения денежного предложения. Федеральным законом от 10.07.2002 № 86- Ф3 «О Центральном банке Российской Федерации (Банке России)» определены основные инструменты и методы влияния Банка России при разработке и реализации денежно кредитной политики.

К ним относятся:

- процентные ставки по операциям Банка России;

- нормативы обязательных резервов, депонируемых в Банке России (резервные требования);

- операции на открытом рынке; 
- рефинансирование кредитных организаций;

- валютные интервенции;

- установление ориентиров роста денежной массы;

- прямые количественные ограничения;

- эмиссия облигаций от своего имени.

Этого всего лишь малая часть, исследования которое становиться все более актуальным, именно сейчас в условиях финансовой нестабильности как страны с развитой экономикой, так и страны с формирующимися рынками. Современная денежно-кредитная система прошла долгий путь развития и перемен, прежде чем достичь нынешнего состояния. Для такого что бы обезопасить будущее, современные условия требуют пересмотра целей всех уровней, на основе полного понимания законов на которых держаться денежно кредитные отношения и система государственного регулирования экономики.

\section{Список литературы:}

1. Игнатовская И.И. Конституционно-правовое регулирование денежнокредитных отношений в Российской Федерации: Автореф. Дис. Канд. Юрид. Наук. Специальность 12.00.02. Томск.2000г. С-21.

2. Онлайн Энциклопедия Кругосвет, Универсальная научно-популярная энциклопедия

https://www.krugosvet.ru/enc/gumanitarnye_nauki/ekonomika_i_pravo/DENG I.html.

3. Hume D. Of money [Электронный pecypc] Режим доступа: https://www.csus.edu/indiv/c/chalmersk/ECON101SP09/HumeOfMoney.pdf (дата обращения 23.05.2020).

4. Кейнс Дж.М. Общая теория занятости, процента и денег [Электронный pecypc] Режим доступа: https:/urait.ru/viewer/the-general-theory-ofemployment-interest-money-obschaya-teoriya-zanyatosti-procenta-i-deneg454946\#/ (дата обращения 23.05.2020).

5. Мишкин Фредерик С. Экономическая теория денег, банковского дела и финансовых рынков [Электронный ресурс] Режим доступа: https://nashol.me/20190710111383/ekonomicheskaya-teoriya-denegbankovskogo-dela-i-finansovih-rinkov-uchebnoe-posobie-dlya-vuzov-mishkinf-1999.html (дата обращения 23.05.2020).

6. Роджер Лерой Миллер, Дэвид Д. Ван-Хуз. Современные деньги и банковское дело [Электронный ресурс] Режим доступа: https://may.alleng.org/d/econ-fin/econ-fin052.htm (дата обращения 23.05.2020).

7. Андрюшин С.А. Денежно-кредитная политика в 2020 году: экспертные оценки. / Банковское дело. 2020 №1. 
8. Андрюшин С.А., Бурлачков В.К., Кирилюк И.Л., Рубинштейн А.А., Случкин Л.Н. Экспертное заключение на проект документа Банка России "Основные напраления единой государственной денежно-кредитной политики на 2020 год и период 2021 и 2022 годов / Банковское дело. 2019 №10.

\title{
SOME ASPECTS OF THE FORMATION OF THE COMPETITIVENESS OF PRIVATE DENTAL ORGANIZATION LLC "KOMODSKIY VARAN"
}

\author{
Darya Naiden \\ Master student, \\ Belarusian State Economic University, \\ Belarus, Minsk \\ Olga Balabanovich \\ Candidate of economic sciences, \\ Belarusian State Economic University, \\ Belarus, Minsk
}

\section{НЕКОТОРЫЕ АСПЕКТЫ ФОРМИРОВАНИЯ КОНКУРЕНТОСПОСОБНОСТИ ЧАСТНОЙ СТОМАТОЛОГИЧЕСКОЙ ОРГАНИЗАЦИИ ООО «КОМОДСКИЙ ВАРАН»}

Найден Дарья Олеговна

магистрант, Учреждение образования «Белорусский государственный экономический университет», Республика Беларусь, г. Минск

Балабанович Ольга Александровна канд. экон. наук, Учреждение образования «Белорусский государственный экономический университет», Республика Беларусь, г. Минск 
Постоянный рост расходов на здравоохранение, связанный с появлением новых медицинских технологий и лекарств, изменениями в структуре заболеваемости и демографическими проблемами, является общей тенденцией для развитых стран мира.[1,2]. Тем не менее, ни одна из стран мира не может бесконечно увеличивать свои расходы на здравоохранение для обеспечения любых возможных вариантов оказания медицинской помощи. При этом важнейшей тенденцией развития систем здравоохранения экономически развитых стран является смещение приоритета от максимальной экономии расходов при оказании медицинской помощи к максимальной эффективности использования задействованных ресурсов [5]. С 1996 года в Республике Беларусь стали развиваться платные медицинские услуги. На сегодняшний день только в городе Минске насчитывается более 150 медицинских центров, между которыми формируются рыночные отношения. Конкурентоспособность частной организации здравоохранения- основной показатель максимально эффективной работы организации в долгосрочной перспективе[1].

\section{Цель}

Разработка комплексного подхода к формированию конкурентоспособности предприятий частной системы здравоохранения для привлечения и удержания клиентов как субъектов предпринимательской деятельности на рынке медицинских услуг на примере ООО «Комодский варан»

\section{Методы исследования}

В исследовании проводилась статистическая обработка собственных данных, полученных путем анализа документации и показателей работы ООО «Комодский варан»

\section{Задачи}

1) обоснованы теоретические положения, определяющие конкурентоспособность частных предприятий здравоохранения как субъектов функционирования сферы услуг;

2) исследованы проблемы конкурентоспособности частных предприятий здравоохранения на рынке медицинских услуг и обосновано отличие понятия конкурентоспособности частных предприятий здравоохранения от конкурентоспособности медицинских услуг;

3) проанализированы и обобщены современные подходы к оценке конкурентоспособности частных предприятий здравоохранения, обоснованы факторы и показатели конкурентоспособности частных предприятий здравоохранения, сложившиеся в мировой практике [1]; 
4) разработаны предложения по формированию конкурентоспособности частных предприятий здравоохранения на рынке медицинских услуг.

\section{Результаты и их обсуждение}

1. Эффективным и доступным для широкого круга пользователей методом изучения конкурентоспособности и формирования конкурентных преимуществ стоматологической медицинской организации является SWOT-анализ ее внутренней среды и ближайших конкурентов. Практически вся необходимая для этих целей информация содержится во внутренних документах организации и открытых источниках, в том числе в Интернете, что обеспечивает доступность использования данного метода для решения поставленных вопросов с минимальными затратами в стоматологических медицинских организациях любой организационноправовой основы и формы собственности.

2. В целом уровень конкуренции на рынке стоматологических услуг Барановичи достаточно высок. В среднем по плотности распределения стоматологических клиник составляет - 2,6 стоматологии на 1 км 2 , а количество жителей города и района, приходящихся на 1 стоматологию - 3473 человека.

3. Потенциальными внешними угрозами для ООО «Комодский варан» являются последствия мирового экономического кризиса и связанное с ними возможное снижение покупательной способности населения, конъюнктура рынка стоматологических услуг, рост конкуренции. Ключевой слабостью организации является полное отсутствие какихлибо маркетинговых исследований, не проводится изучение даже ближайших с поликлиникой конкурентов, не ведется работа по привлечению новых пациентов, полностью отсутствует реклама поликлиники, в то время как ее производственные мощности позволяют обслужить дополнительные группы потребителей.

4. Потенциальными внутренними силами роста и развития ООО «Ко-модский варан» являются опытные высококвалифицированные кадры, наличие в клинике современных технологий и материалов, комплексное качественное лечение и внимательное отношение к пациентам, удобное месторасположение клиники и график работы. Реальной внешней возможностью для повышения конкурентоспособности организации является не полностью занятая ниша на рынке стоматологических услуг - имплантология.

5. Эффективным методом рекламы выполняемых в стоматологической медицинской организации услуг, а в итоге и всей организации в целом, является создание небольших тематических сайтов, посвященных 
отдельным видам этих услуг. Создание тематического сайта по продвижению оказываемой в ООО «Комодский варан» специальной услуги «лечение зубов под наркозом» позволило привлечь в среднем до 14 новых пациентов в месяц. Средняя стоимость терапевтического и хирургического лечения одного пациента, обратившегося в ООО «Комодский варан» по рекламе сайта, составила 1564 руб. в 2019 г. и 1449 руб. в 2020 г., а суммарные финансовые поступления - соответственно $69 \%$ и $76 \%$ от общей суммы уплаченной всеми пациентами, прошедшими лечение под наркозом в указанные годы.

6. Суммарные затраты на создание и открытие кабинета дентальной имплантации ООО «Комодский варан» в 2019 г., включая ремонт помещений (6150 руб.), обучение персонала (6300 руб.) и оснащение кабинета (39758 руб.), составили 52568 руб. К 2020 г. финансовые поступления от деятельности кабинета полностью компенсировали затраты на его создание и обеспечили клинике дополнительный доход.

7. Современное население весьма тщательно и глубоко проводит собственный маркетинг стоматологических услуг при выборе той или иной стоматологической медицинской организации. Достаточно высокий процент пациентов ООО «Комодский варан» желающих продолжить в нем лечение (в среднем 77,32 $\pm 1,99 \%$ ) прямо свидетельствует о высокой конкурентоспособности данной стоматологической медицинской организации.

Практические рекомендации:

1. Для поддержания конкурентоспособности стоматологической медицинской организации на должном уровне, SWOT-анализ ее внугренней и внешней среды целесообразно проводить не реже одного раза в год (при необходимости - чаще), с целью оценки влияния реализованных мероприятий на конкурентоспособность организации и принятия решения о корректировке или изменении выбранной стратегии.

2. В качестве основных конкурентов целесообразно выбирать ближайшие стоматологические организации равной ценовой категории и проводить с ними сравнительный анализ по выполняемым услугам, ценам, рекламной деятельности.

3. Разработанная анкета может быть использована для проведения социологического исследования среди пациентов стоматологической медицинской организации любой формы собственности.

4. Эффективным методом рекламы выполняемых в стоматологической медицинской организации услуг, а в итоге и всей организации в целом, является создание небольших тематических сайтов по конкретным видам стоматологических услуг. 
5. Реальной внешней возможностью для повышения конкурентоспособности стоматологических медицинских организаций является не полностью занятая ниша на рынке стоматологических услуг - имплантология.

\section{Список литературы:}

1. Амхадова М.А. Конкурентоспособность предприятия в сфере стоматологических услуг: SWOT-анализ на примере конкретного предприятия / М.А. Амхадова, А.А. Никитин, А.М. Клюев, А.Ю. Игнатов, Н.М. Мустафаев, Р.С. Гаджиев.- Москва:КрисЛИТ, 2011.- 357 с.

2. Кульпанович О.А. Организация здравоохранения. трудовые показатели, нормирование, финансово-хозяйственная деятельность: тестовые задания: учеб.-метод. пособие / О.А. Кульпанович. - Минск: БелМАПО, 2016. -200 с.

3. Ткачева Е.И. Функционирование системы здравоохранения Республики Беларусь в изменяющихся экономических условиях / Е.И. Ткачева // Вопро-сы организации и информатизации здравоохранения. - 2017. - №4. - 27-31 с.

4. Chalkley M., J. Malcomson. Government Purchasing of Health Services, in A.J. Culyer, J.P. Newhouse (eds.) Handbook of Health Economics / M. Chalkley, J. Malcomson // N.Y. and Oxford: Elsevier Science, North-Holland. 2000. - P. 847-90.

5. Office of Fair Trading. Dentistry, an OFT market study (OFT1414) [Электронный ресурс].- 2012. 


\title{
SECTION 7.
}

\author{
LAW
}

DOI: 10.32743/NetherlandsConf.2021.3.5.255155

\section{NOWADAYS GAMBLING INDUSTRY REGULATION IN RUSSIA AND EX-USSR}

Helga Ozolina

Gambling Analytics EU LLC, Head of Legal Dept, Latvia, Jurmala

\section{СУЩЕСТВУЮЩЕЕ РЕГУЛИРОВАНИЕ ИНДУСТРИИ АЗАРТНЫХ ИГР В РФ И СТРАНАХ БЫВШЕГО СССР}

\author{
Хельга Озолина \\ руководитель юридчческого отдела, \\ ООО Гемблинг Аналитикс Европа, \\ Латвия, г. Юрмала
}

На сегодняшний день индустрия азартных игр в Российской Федерации регулируется Федеральным законом от 29.12.2006 № 244Ф3 «О государственном регулировании деятельности по организации и проведению азартных игр и о внесении изменений в некоторые законодательные акты Российской Федерации».

Данным нормативно-правовым актом определены правовые основы государственного регулирования деятельности по организации и проведению азартных игр на территории нашей страны и установлены ограничения осуществления указанной деятельности в целях защиты нравственности, а также прав и законных интересов граждан.

Под азартной игрой понимается основанное на риске соглашение о выигрыше, заключенное двумя или несколькими участниками такого соглашения между собой либо с организатором азартной игры по правилам, установленным организатором азартной игры.

Государственное регулирование в рассматриваемой индустрии 
заключается в следующем:

- Определение порядка осуществления деятельности по организации и проведению азартных игр и установление соответствующих ограничений и обязательных требований к организаторам азартных игр, игорным заведениям, посетителям игорных заведений, игорных зон;

- Определение игорных зон (территорий, предназначенных для организации и проведения азартных игр);

- Выдача разрешений на организацию и проведение азартных игр в игорных зонах;

- Выдача лицензий на организацию и проведение азартных игр в букмекерских конторах или тотализаторах;

- Государственный надзор в сфере организации и проведения азартных игр, который направлен на предупреждение, выявление и пресечение нарушений законодательства о государственном регулировании деятельности по организации и проведению азартных игр лицами, осуществляющими указанную деятельность.

На сегодняшний день в Российской Федерации существует пять игорных зон, которые располагаются на территории следующих субъектов Российской Федерации: Алтайский край, Краснодарский край, Приморский край, Калининградская область и Республика Крым.

Уголовный кодекс Российской Федерации, а именно статья 171.2 предусматривает наказание за организацию или проведение азартных игр с использованием игрового оборудования вне игорной зоны либо с использованием информационно-телекоммуникационных сетей, в том числе сети «Интернет».

Административная ответственность за незаконную организацию и проведение азартных игр с использованием игрового оборудования вне игровой зоны либо с использованием информационно-телекоммуникационных сетей закреплена в статье 14.1.1 КоАП РФ.

Помимо этого, распространение рекламы онлайн-казино также влечет ответственность для владельца сайта, разместившего такую информацию в силу ч. 2 ст. 27 Федерального закона от 13.03.2006 №38Ф3 «О рекламе», запрещающей публикацию рекламы основанных на риске игр и пари в сети «Интернет».

На сегодняшний день одним из самых громких уголовных дел в рассматриваемой индустрии является «Дело о подмосковных казино» [1] или, как его еще называют, «Дело подмосковных прокуроров». Речь идет об уголовном деле 2011 года о подпольном игровом бизнесе в Подмосковье, известность которому дал последующий межведомственный конфликт Следственного комитета РФ и Прокуратуры РФ [2]. Особенностью этого уголовного дела являлась поддержка обвиняемых 
работниками надзорного ведомства - прокурорами, причем, значительная часть подозреваемых сами были высокопоставленными прокурорами, либо их друзьями или родственниками.

Еще одним громким делом является дело «игорного короля» Антона Бажанова, в рамках которого в один день в разных районах Москвы было закрыто 15 подпольных казино, большинство которых было замаскировано под букмекерские конторы [3], а одно и вовсе работало на территории посольства КНДР. Примечательно, что Антон Бажанов был задержан в легальном казино «Сочи» в Красной Поляне прямо за игровым столом.

В январе 2020 года следственными органами было возбуждено уголовное дело в отношении 15 жителей Новгородской области, которых подозревали в организации и проведении незаконных азартных игр, доход от которых превысил 143 миллиона рублей. По данным следствия нелегальный игорный бизнес был организован жителем Великого Новгорода, а азартные игры с использованием специального оборудования и сети «Интернет» проводились в помещениях многоквартирных домов.

На Украине индустрия азартных игр регулируется Законом Украины от 14.07.2020 №768-IX «О государственном регулировании деятельности по организации и проведению азартных игр». В соответствии с указанным законом, в Украине разрешается ведение следующих видов игорного бизнеса:

- Организация азартных игр в казино и онлайн-казино;

- Прием ставок в букмекерских конторах, в том числе через «Интернет»;

- Открытие залов игровых автоматов;

- Проведение онлайн-игр в покер (при этом турниры по спортивному покеру азартной игрой не считаются).

Согласно законодательству Украины, под азартной игрой понимается любая игра, условием участия в которой является внесение игроком ставки, которая дает право на получение выигрыша (приза), вероятность получения и размер которого полностью или частично зависит от случайности, а также знаний и мастерства игрока.

В Республике Беларусь индустрия азартных игр регулируется рядом указов президента и постановлений, среди которых следует выделить: Указ Президента Республики Беларусь от 10.01.2005 №9 «Об утверждении Положения об осуществлении деятельности в сфере игорного бизнеса на территории Республики Беларусь», Указ Президента Республики Беларусь от 19.11.2010 №599 «О некоторых мерах по совершенствованию порядка осуществления деятельности в сфере игорного бизнеса».

На сегодняшний день в Республике Беларусь разрешены следующие виды азартных игр: казино, национальные лотереи, залы игровых 
автоматов, тотализаторы, букмекерские конторы, онлайн-казино, мгновенные лотереи в сети «Интернет». Определение термина «азартная игра», содержащееся в законодательстве Республики Беларусь почти полностью совпадает с определением, содержащимся в российском законодательстве.

В Республике Казахстан индустрия азартных игр регулируется Законом Республики Казахстан от 12.01.2007 №219-III «Об игорном бизнесе». Определение термина «азартная игра», содержащееся в данном Законе идентично определению, содержащемуся в российском законодательстве.

В Республике Казахстан осуществляются следующие виды деятельности в сфере игорного бизнеса: казино, зал игровых автоматов, букмекерская контора, тотализатор.

В Грузии индустрия азартных игр регулируется Законом Грузии «Об устройстве лотерей, азартных и прибыльных игр» №5448 от 09.12.2011. Согласно данному Закону под азартной игрой понимается игра, результат которой полностью или частично зависит от случайности. Организация азартных игр (кроме азартного турнира) допускается только в казино, салоне игровых аппаратов или (и) в клубе азартных игр. Примечательно, что согласно законодательству Грузии к лотерее, азартным и прибыльным играм не относятся игры, проводимые с использованием машин, аппаратов, устройств и иных средств, и в которых не предусмотрен элемент случайности.

В Армении в виду внесения изменений в Закон Армении «Об азартных играх» с ноября 2020 года закрыты все игорные заведения, в том числе букмекерские конторы и тотализаторы. Премьер-министр Армении Никол Пашинян является ярым противником азартных игр, именно он стал инициатором многочисленных запретов в отношении игорного бизнеса.

В Республике Таджикистан индустрия азартных игр регулируется рядом нормативно-правовых актов: «Порядок проведения лотерей в Республике Таджикистан» от 3 июля 2002 г., «Порядок выдачи Свидетельства субъектам лотерей на организацию лотерейной деятельности» от 16 мая 2003 г., Положение «О порядке лицензирования в области организации азартно-развлекательных и компьютерных игр, игровых автоматов (кроме организации и проведения денежно-вещевых лотерей и казино)» от 14 июня 2002 г.

В Азербайджане на сегодняшний день игорный бизнес на государственном уровне находится под запретом, разрешенными операциями на территории страны являются только лотерейные и букмекерские. В Узбекистане азартные игры законодательно запрещены, следствием чего является отсутствие наземных и онлайн-казино. 
В Республике Молдова индустрия азартных игр регулируется Законом Республики Молдова от 18.02.1999 года №285-XIV «Об азартных играх», согласно которому под азартной игрой понимается проводимая в соответствии с правилами игра, участие в которой позволяет выигрывать деньги, иное имущество или имущественные права, а результат определяется действиями, полностью или частично основанными на случае.

В Литве индустрия азартных игр регулируется Законом № IX-325 «Об игорном бизнесе» от 17.05.2001 года, в Латвии - Законом «Об азартных играх и лотереях» от 17.11.2005 года, в Эстонии - Федеральным законом «Об азартных играх».

\section{Список литературы:}

1. Чайка назвал бездоказательным дело подмосковных прокуроров, Forbes, 12.02.2014.

2. Вексельный терминал как способ легализации азартных игр в России, Ирина Цветкова, Administratīvā un Kriminālā Justīcija Nr. 2/2019.

3. Криминалистическая характеристика легализации (отмывания) доходов, полученных преступным путем, Жамбалов Дмитрий Баирович, Криминалистика. Судебно-экспертная деятельность. Оперативнорозыскная деятельность, 4 (91) 2019. 


\title{
ON THE NEED TO STRENGTHEN THE PROTECTION OF VIRTUAL SPACE IN THE CONTEXT OF A PANDEMIC
}

Olga Korotkova

cand. yurid. PhD, Senior lecturer Moscow Academy of the Investigative Committee, Russia, Moscow

\section{О НЕОБХОДИМОСТИ УСИЛЕНИЯ ЗАЩИТЫ ВИРТУАЛЬНОГО ПРОСТРАНСТВА В УСЛОВИЯХ ПАНДЕМИИ}

\author{
Короткова Ольга Валерьевна \\ канд. юрид. наук, ст. преподаватель, \\ Московская академия следственного комитета, \\ РФ, г. Москва
}

В условиях развития коронавирусной инфекции сетевое сообщество стало объединяющим фактором формирования межгосударственных отношений в виртуальном пространстве. Проблема защита информации стала выходить на первый план. В период (данные на 1 июня 2020 года), когда в мире было выявлено 6.235.786 случаев заболевания коронавирусом, мировое сообщество было вынуждено находиться в режиме самоизоляции. Так, по данным «The Norton Cyber Security Insights Report» в Республике Беларусь названная цифра приближалась к 6 тысячам, в Республике Казахстан - к 5 тысячам, в Республике Узбекистан - к 4 тысячам, в Российской Федерации - к 7 тысячам.

В этот период, когда население Земли практически перешло к общению посредством сети Интернет, остро встал вопрос глобального обеспечения информационной безопасности.

Полагаем, что особые аспекты, составляющие угрозу информационной безопасности мирового сообщества можно выделить в следующем:

1. Незаконное распространение в сети Интернет заведомо ложного контента информачии.

Именно процесс расширения пандемии привел к массовому 
использованию сети Интернет, возрастанию потока информации, в том числе, ложной и необработанной в виртуальном пространстве.

По мнению правоведа В. Павловцева именно фейковая информация стала зачастую восприниматься мировым сообществом как истинная, вследствие следующих моментов [2, с. 35]:

- ложная (фейковая) информация стала восприниматься населением как обычный новостной контент;

- каждую шестую ложную новость легко можно обнаружить в Google;

- большая трудность в выборке истинной информации в большом массиве фейков.

Так, правовед Т. Хусяинов отмечает, что в сложившихся условиях каждый восьмой россиянин утверждает, что (COVID-19) - это «выдумки международного сообщества» и не воспринимает официальные статистические данные по нему [3, с. 54].

По нашему мнению, названные факты свидетельствуют о постоянном росте в период пандемии негативного контента, вбрасываемого в виртуальную среду, вызывающего рост недовольства населения и, в первую очередь, самой активной его части - молодежи.

2. Возрастание в сети Интернет экономически, политически и социально мотивированных онлайн преступлений.

В течение года пандемии резко обозначилось падение уровня правосознания населения в рамках мирового сообщества. Этому следует привести примеры неподчинения части населения правоохранительным структурам, выражающееся в регулярном нарушении правил, введенных в условиях карантина, в игнорировании запретов, а также введенных мер безопасности. Так, за первые 3 месяца 2020 года в Республике Беларусь было выявлено 156235 административных правонарушений, в Республике Казахстан - 148112, в Республике Узбекистан - 163453, а в Российской Федерации - 142678 административных правонарушений.

Согласно данным статистики опрошенные пользователи виртуального пространства предпочитают использовать сети для доступа к политической $(56 \%)$, экономической $(47 \%)$ информации и данным по социальной сфере (44\%), используя в первую очередь коммуникации YouTube, Twitter, Instagram.

Как отмечают в своих работах А. Шидловский и А. Цветков, именно низкий уровень правосознания населения, а также анонимность и легкодоступность Интернета способствуют росту в виртуальной среде экономически, политически и социально мотивированных онлайн преступлений [4, с. 28]. К подобным преступлениям, парализующим систему информационной безопасности следует отнести следующие их виды: 
- усиление кибертерроризма в виртуальной среде, использующего виртуальное пространство для запугивания определенных слоев населения и распространения пропагандистских лозунгов;

- рост спама, в том числе, увеличение оскорбительных сообщений, касающихся расовой, религиозной, гендерной, национальной и иной принадлежности;

- увеличение фишинг операций, содействующих преступному вымогательству в виртуальной среде электронных денег населения посредством рассылки ложных писем из фиктивных банков в условиях пандемии;

- разрастание кибербуллинга или операций по использованию виртуального пространства в целях запугивания и унижения пользователей (в том числе, детей).

3. Рост преступлений в сети «DarkNet» или «Dark Web» («тёмная паутина», называемая глубоким Интернетом или изнанкой сети).

Как показывают материалы практики «DarkNet» это закрытая (скрытая) сеть Интернет, параллельно существующая с обычным виртуальным пространством. Данные сети анонимны, а вся имеющаяся информация зашифрована. Другими словами, «DarkNet» это сеть внутри сети.

Важно отметить, что «DarkNet» располагает собственными поисковыми системами, новостными сайтами, интернет-магазинами и социальными системами. Однако, большая часть этих сайтов зачастую занимается нелегальной преступной деятельностью, а именно:

- распространением в виртуальной среде противозаконной порнографии (в том числе, детской) как сегмента экстремистской направленности;

- внедрением сетевого груминга, связанного с сексуальными домогательствами до несовершеннолетних, которые распространяются, к примеру, в онлайн играх для детской аудитории;

- предложением киллерских услуг в виртуальной среде;

- пропагандой в виртуальной среде наркотиков, оружия и иных запрещенных товаров.

Анализ роста количества преступлений в виртуальной среде показал, что в условиях пандемии усилились следующие противоправные способы, используемые преступниками в период самоизоляции граждан:

- распространение вредоносных программ в сети Интернет;

- усиление DDOS атак, выводящих в короткий срок объект воздействия;

- рост числа зашифрованных сообщений, скрытых профайлов и иных подобного плана технологий [1, с. 49]. 
Полагаем, что на рост преступлений в виртуальной среде в период пандемии повлияло, в первую очередь, отсутствие необходимых знаний в области виртуального пространства в сети Интернет. Вследствие этого, в сложившихся условиях рекомендуем разработать систему дополнительного образования в виртуальном пространстве в условиях пандемии, которая включала бы в себя:

во-первых, введение специального предметного изучения вопросов информационной безопасности на уровне обучения навыкам первичного пользования сетями Интернет в общеобразовательных школах, включая видео-уроки;

во-вторыx, организацию процесса подготовки специалистов в системе высшего образования, то есть кадров, обладающих как общеправовыми, так и техническими знаниями обеспечения информационной безопасности в виртуальном пространстве;

в-третьих, разработку комплексных программ дополнительного образования и переподготовки кадров, осуществляющих работу по обеспечению информационной безопасности в правоохранительных структурах.

\section{Список литературы:}

1. Батухтин М.Е. Киберпреступления: причины, виды, формы, последствия, направления противодействия // Проблемы и перспективы развития уголовно-исполнительной системы России на современном этапе Материалы Международной научной конференции адъюнктов, аспирантов, курсантов и студентов. 2020.

2. Павловец В.И. России нужны не биороботы, а креативный средний класс: о направлениях эффективного реформирования экономики и образования / В.И. Павловец // Альманах современной науки и образования. 2020.

3. Хусяинов Т.М. Интернет-преступления (киберпреступления) в российском уголовном законодательстве // Уголовный закон Российской Федерации: Проблемы правоприменения и перспективы совершенствования материалы всероссийского круглого стола. 2020.

4. Шидловский А.В., Цветков А.Н. Установление уголовной ответственности за киберпреступления - новый сегмент в правовой охране электронного государства // Сборник материалов VI Международной науч.-практ. конф. 2019. 


\title{
INNOVATIONS AND TENDENCIES OF STATE-OF-ART SCIENCE
}

\author{
Proceedings of V-VI international Multidisciplinary Conference
}

April, 2021

Published in author's edition

The opinions expressed by the authors may not coincide with those of the editorial.

Signed to print 12.04.21. Paper size 60x84/16.

Offset paper No.1. Typeface Times. Digital print.

Conventional printed sheet 5,75 . Printing run 550 copies.

Publishing House "Mijnbestseller Nederland"

Delftsestraat 33, 3013 AE Rotterdam, Nederland

Printed in full accordance with the quality of the provided original layout in the printing office "Allprint"

3, Vokzalnaya magistral Street, Novosibirsk, 630004 
